\title{
Oxidative Damage and Bronchial Asthma
}

\author{
Eva Babusikova, Jana Jurecekova, Andrea Evinova, \\ Milos Jesenak ${ }^{1}$ and Dusan Dobrota \\ Comenius University in Bratislava, Jessenius Faculty of Medicine in Martin, \\ Department of Medical Biochemistry \\ ${ }^{1}$ Department of Paediatrics \\ Slovakia
}

\section{Introduction}

All organisms live in the environment that contains oxygen which is vital for all aerobic organisms, and reactive oxygen species (ROS) which are formed in cells as a consequence of aerobic metabolism. Moreover mitochondrial respiration (a base of energetic production in all eukaryotic organisms) is associated with an inevitable electron leak, resulting in a nonstop production of reactive oxygen species, such as superoxide anion radical, hydrogen peroxide and hydrogen radical. Universal nature of reactive oxygen species is underlined by the presence of one enzyme - superoxide dismutase. This enzyme occurs in all aerobic organisms and it is responsible for dismutation of superoxide anions into oxygen and hydrogen peroxide. Genes involved in detoxification of reactive oxygen species are highly conserved among eukaryotes and their deficiency could be limit of several diseases and life span. Oxidative stress is a unique pathophysiological condition resulting from the disrupted balance between oxidants and antioxidants. Increased level of reactive oxygen species may cause oxidative damage of all biomolecules: nucleic acids, proteins, lipids, saccharides. A progressive grow of oxidative damage is the result of increasing production of reactive oxygen species or an insufficient antioxidant defence system and this damage may contribute to the origin and development of several diseases including bronchial asthma, but on the other hand oxidative damage can be the consequence of them as well (fig. 1).

The lungs have the highest exposure to atmospheric oxygen. This organ is vulnerable to oxidative damage by oxygen and pollutants (tobacco smoke, ozone, silicon, asbestos, oxides of nitrogen and sulphur) because of its location, anatomy and function. The large endothelial surface $\left(100 \mathrm{~m}^{2}\right)$ makes the lungs a major target site for circulating oxidants and xenobiotics. Bronchial asthma is the most frequent chronic respiratory disease in children. It is characterized by on-going airway inflammation commonly associated with airway remodelling. Oxidative damage is not only result of non-controlled airway inflammation but it can be a significant factor in the provoking of asthma exacerbations and in the maintenance of asthmatic symptoms, and may play one of the essential roles in the development and persistence of bronchial asthma. Oxidative damage may represent a potential target of the treatment of bronchial asthma. 
Endogenous production of ROS occurs in vivo as by-products of enzymatic redox chemistry and traces of the iron and other metals catalyse oxidative reaction in vivo. Production of highly reactive oxygen species causes progressive, causal damage of nuclear DNA, mitochondrial DNA, RNA, enzymes, other proteins as well as unsaturated fatty acids and phospholipids. These kinds of damage may lead to a cell damage, changed cell function, and finally to a cell death.

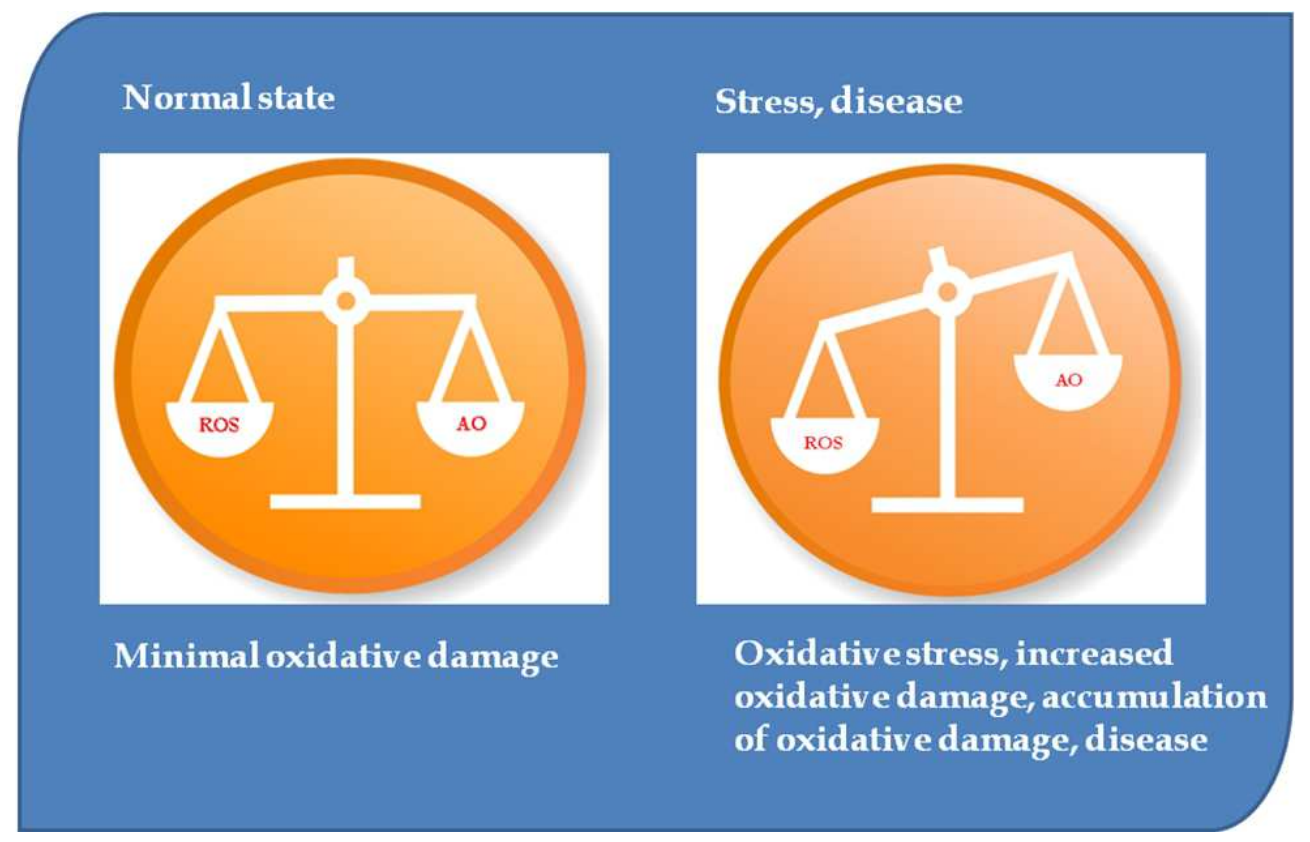

Fig. 1. Reactive oxygen species in the development of disease. As a consequence of disturbed equilibrium between reactive oxygen species (ROS) and antioxidants (AO) on the side of ROS, oxidative stress is increased. This causes increased oxidative damage of biomolecules, its accumulation, and the development of several diseases.

\section{Origin of reactive oxygen species}

Higher eukaryotic organisms cannot exist without oxygen. Molecular oxygen is essential for energy production in its diatomic basic state $\left(3 \sum \mathrm{g}-\mathrm{O}_{2}\right.$ or $\left.\mathrm{O}_{2}\right)$. During a lot of primary intracellular reactions in which oxygen is necessary, reactive oxygen species are produced. Oxygen and reactive oxygen species have destructive properties that can explain wide palette of medical states which become during origin and duration of many diseases. Single oxygen is not extremely reactive. Oxygen has two unpaired electrons which have parallel spin quantum number and they are localized in different molecular orbital and therefore oxygen molecule is quantified as diradical. If oxygen wants to accept two electrons both of them could have antiparallel spin. This criterion is executed very rarely in a typical electron pair. Therefore oxygen accept electrons for one in time and in vivo it is typical two- or four- 
electron reduction of oxygen using coordinating, serial enzymatic catalysed one-electron reductions (Beckman \& Ames, 1998).

Reactive oxygen species are created in the organism under normal physiological conditions after controlled stimulation like by-product of some biological processes. There are several sources of exogenous oxidant production as well (fig. 2). Four from the endogenous sources (mitochondria, phagocytes, peroxisomes, and cytochrome $\mathrm{P}_{450}$ enzymes) are responsible for origin of the majority of oxidants produced by cells (Ames et al. 1993).

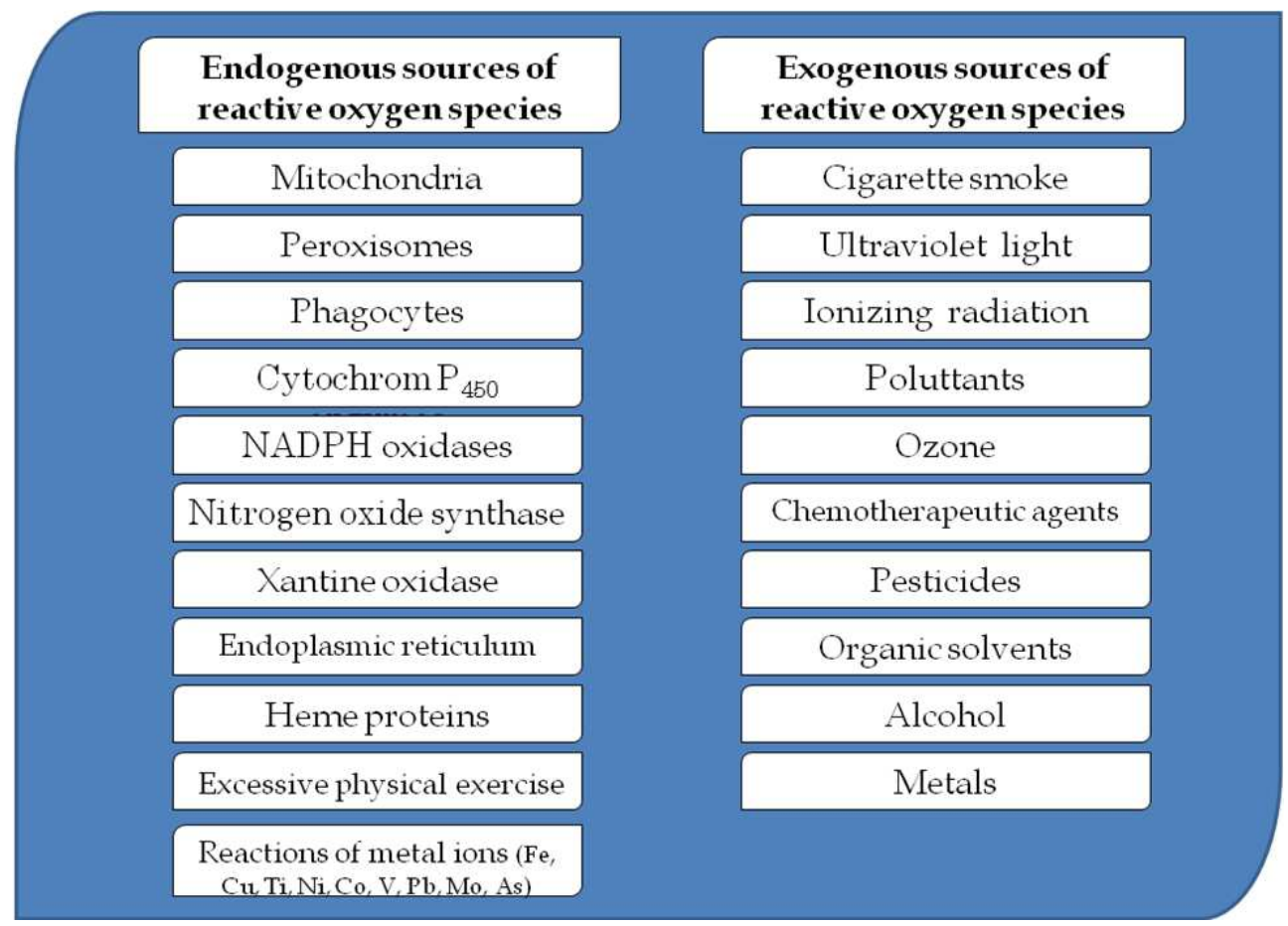

Fig. 2. Endogenous and exogenous sources of reactive oxygen species.

The main endogenous source of reactive oxygen species are mitochondria which produce reactive oxygen species continuously. The main mitochondrial function is energy production. In normal aerobic respiration mitochondria utilize oxygen that is reduced by serial steps whereby is produced water $\left(\mathrm{H}_{2} \mathrm{O}\right)$. Mitochondria are the major producer of reactive oxygen species via incomplete reduction of oxygen by electrons leaked out of the respiratory chain in the animal and human cells. It has been demonstrated that NADHcoenzyme $\mathrm{Q}$ oxidoreductase (Complex I) and ubiquinol-cytochrome c reductase (Complex III) of the respiratory chain are the major sites that generate reactive oxygen species in animal mitochondria. Mitochondrial oxidative damage can lead to the release of greater amount of reactive oxygen species and cause increased oxidative damage of mitochondrial, 
cytoplasmic and nuclear components what subsequently may lead to dysfunctional mitochondria. Damage of mitochondrial electron transport may be an important factor in the pathogenesis of many diseases.

Phagocytig cells are another important endogenous source of oxidants. The main function of phagocytosis is the defence of host organisms against pathogens, conditionally pathogenic micro-organisms and foreign as well as body own particles bigger than $0.1 \mu \mathrm{m}$. Neutrophils and another phagocytes attack pathogens by mixture of reactive oxygen species: singlet oxygen $\left(\mathrm{O}_{2}{ }^{\bullet}-\right)$, nitric oxide $\left({ }^{\circ} \mathrm{NO}\right)$, hydrogen peroxide $\left(\mathrm{H}_{2} \mathrm{O}_{2}\right)$, hypochlorous acid $(\mathrm{HClO})$ (Pollack \& Leeuwenburgh, 1999). Chronic virus, bacterial or parasite infection results in chronic increased phagocyting activity and finally chronic inflammation, which is a main risk factor for development of several diseases (Ames et al., 1993), and raising oxidative damage.

Peroxisomes are organelles from the microbody family and are present in almost all eukaryotic cells. They participate in the $\beta$-oxidation of fatty acids and in the metabolism of many others metabolites. Certain enzymes within peroxisome, by using molecular oxygen, remove hydrogen atoms from specific organic substrates, in an oxidative reaction, producing hydrogen peroxide. Hydrogen peroxide is degraded by catalase, another enzyme in peroxisome (Beckman \& Ames, 1998). Peroxisomes contain also xanthine oxidase which produces singlet oxygen and hydrogen peroxide.

Microsomal cytochrome $\mathbf{P}_{450}$ enzymes are a very large and diverse superfamily of hemoproteins identified from all lineages of life including humans, mammals, birds, fish, plants, bacteria. They form one of the primary defence system against xenobiotic compounds usually plant origin. Human cytochrome $\mathrm{P}_{450}$ enzymes are primarily membrane-associated proteins, located in the inner mitochondrial membrane or in the endoplasmic reticulum of cells. They modify thousands of endogenous and exogenous compounds by univalent oxidation or reduction. Induction of these enzymes protects from acute oxidative effects of foreign compounds or chemicals but also results in production of oxidants.

The main cellular sources of ROS in the lung include neutrophils, eosinophils, alveolar macrophages, alveolar epithelial cells, bronchial epithelial cells and endothelial cells (Kinnula et al., 1992, 1995).

\subsection{Types of reactive oxygen species}

Reactive oxygen species are chemical units which are divided into two groups: free radicals and non-radical compounds (fig. 3). Free radical or radical is an atom, molecule or compound which has, contrary to non-radical atoms, one or more unpaired electrons.

One of the basic properties of reactive oxygen species is their extreme reactivity. Reactive oxygen species oxidize molecules and therefore they are named oxidant. They can also act as a reducing factor, can be electron neutral but also can have positive or negative charge. Radicals are predominantly high reactive and they initiate complex line of consequential reactions by which other new reactive oxygen species are formed. Results of these series reactions are chemical modification of amino acids, peptides, proteins, nucleotides, nucleic acids, fatty acids, lipids and saccharides. Structural changes of biological molecules, which are situated in the proximity of their reactive species cause change of their biological 
function. Reactive oxygen species participate on regulation of several physiological functions of cells and organisms such as cell signalling, neurotransmission and regulation of neurotransmitters release, gene expression, metabolism, cell proliferation and grow cells, immunity answer, and control of contraction and relaxation of smooth muscles, respiration, cell death (Chan, 2001; Halliwell and Gutteridge, 1999; Hanafy et al., 2001; Kroncke, 2001). Control of signal (Chan, 2001; Kroncke, 2001) and metabolic pathways (Halliwell and Gutteridge, 1999; Hanafy et al., 2001) through reactive oxygen species has meaning not only during physiological state of organism but supposes that during definite conditions deregulation of reactive oxygen species production participate on various kinds of diseases.

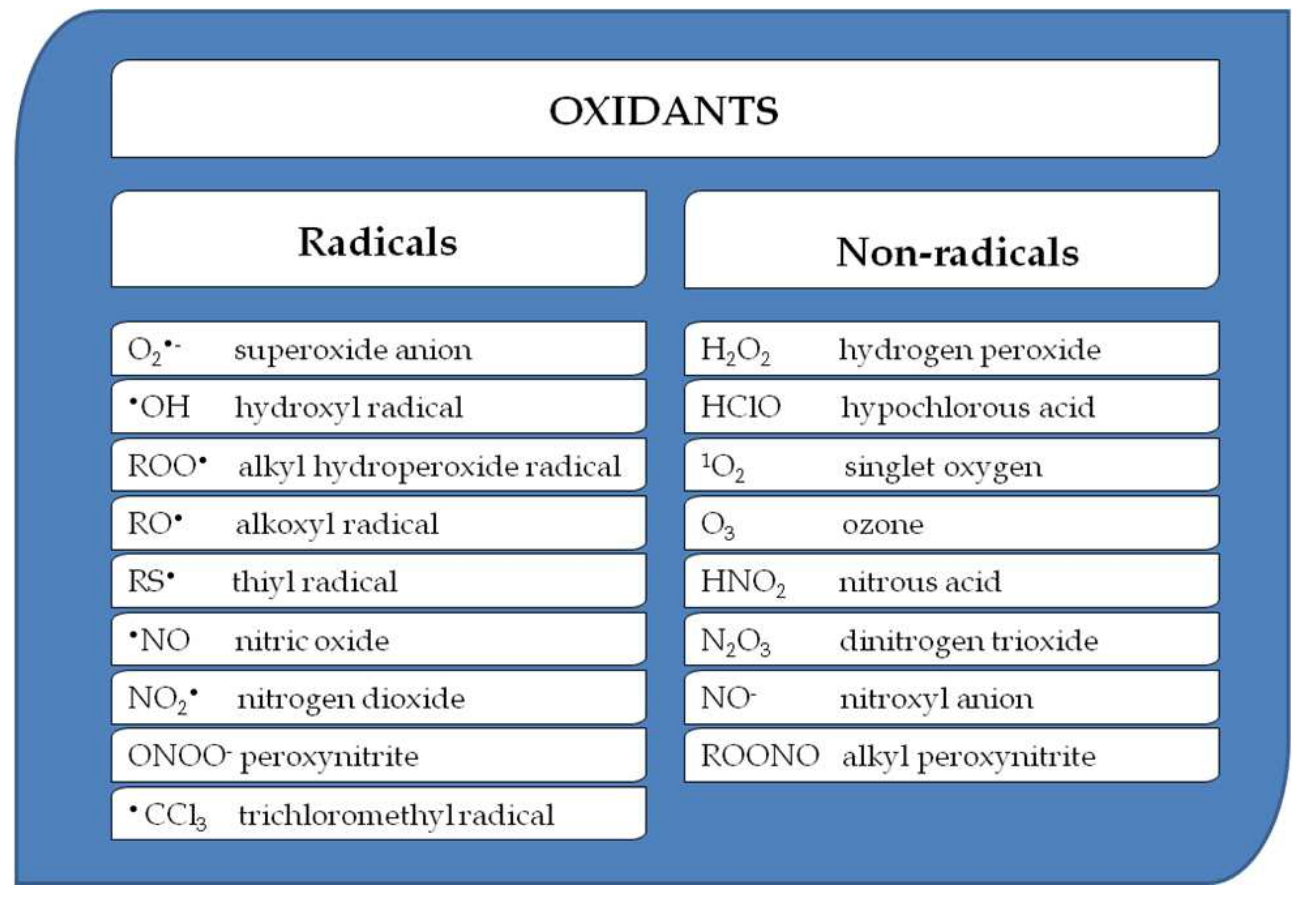

Fig. 3. Examples of reactive oxygen species.

\subsection{Antioxidant defense}

Reactive oxygen species are necessary for human life. Many vital events are mediated by radical reactions in organism. Reactive oxygen species serve as signal molecules in low concentrations but if they are produced in oversize amount evoke harmful, destructive effects (Dhalla et al., 2000). Toxicity connected with inadequate production of these species is prevented by antioxidant defence systems that provides healthy cell environment. Cells possess enzymatic and non-enzymatic defence systems (dietary antioxidants, extracellular compounds that have antioxidant activity) (fig. 4) (Bergendi et al., 1999; Pollack \& Leeuwenburgh, 1999). 
Superoxid dismutase (SOD, EC 1.15.1.1) is universal enzymatic antioxidant. This enzyme is extremely efficient and catalyses the neutralization of superoxide anion to oxygen and hydrogen peroxide. There are three major families of superoxide dismutase, depending on the metal cofactor: $\mathrm{Cu} / \mathrm{Zn}$ (which binds both copper and zinc), Fe and Mn types (which bind either iron or manganese), and the Ni type (which binds nickel). In humans three form of SOD are present: cytoplasmic $\mathrm{Cu} / \mathrm{Zn}-\mathrm{SOD}$ (SOD1), mitochondrial Mn-SOD (SOD2), and extracellular $\mathrm{Cu} / \mathrm{Zn}-\mathrm{SOD}$ (ECSOD, SOD3).

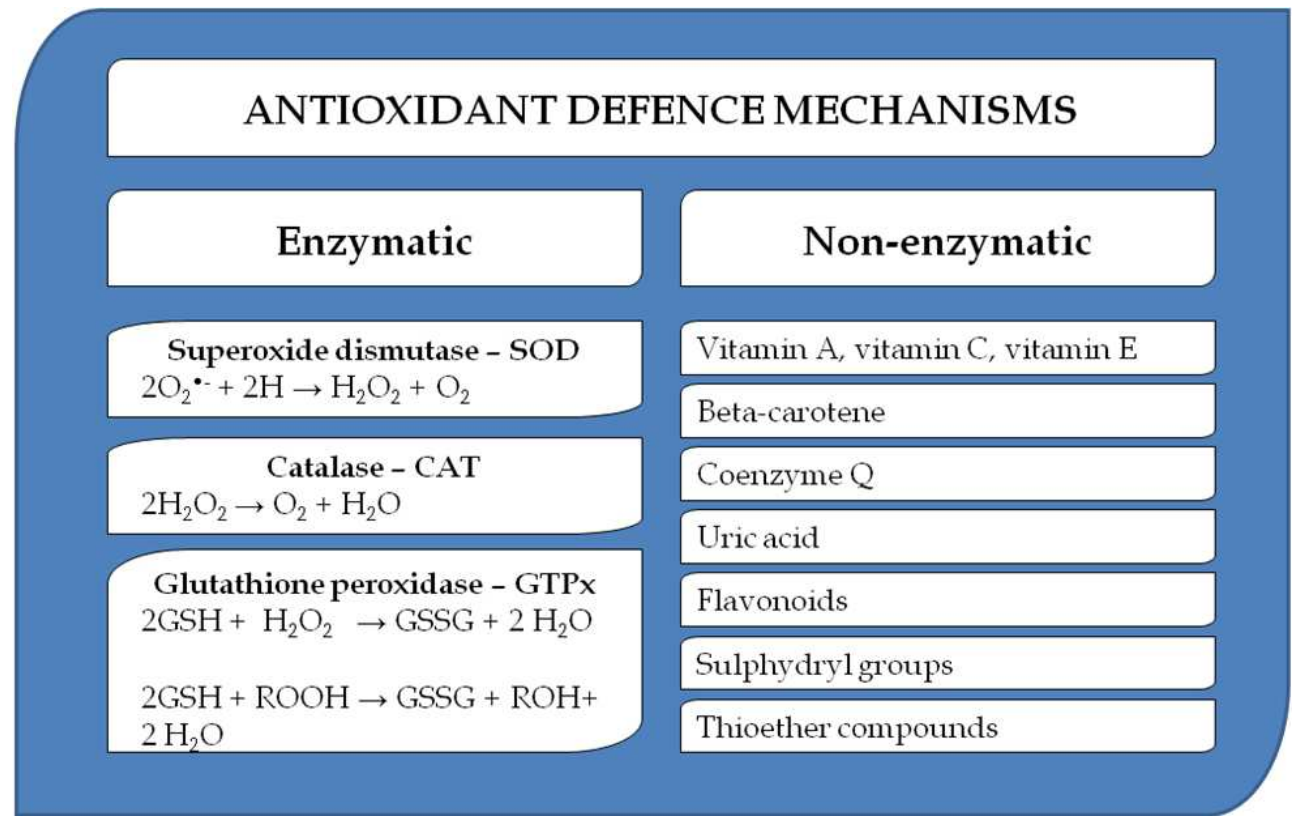

Fig. 4. Antioxidant defence systems in organism. $\mathrm{O}_{2}{ }^{\bullet}$, , superoxide anion; $\mathrm{GSH}$, glutathione; GSSG, glutathione disulfide; $\mathrm{ROOH}$, alkyl hydroperoxide.

Catalase (CAT, EC 1.11.1.6) is a common antioxidant enzyme responsible for controlling hydrogen peroxide concentrations in cells. It is ubiquitous to most aerobic cells and is situated in the lungs as well (macrophages, fibroblasts, and pneumocytes) (Kinnula et al., 1995). Catalase as an intracellular antioxidant enzyme catalyzes the decomposition of two molecules of hydrogen peroxide into one molecule of oxygen and two of water and its activity is genetically determined.

Glutathione peroxidases (GPXs, EC 1.11.1.9) are family of enzymes ubiquitously distributed which have peroxidase activity whose a main biological role is to protect the organism from oxidative damage. Glutathione peroxidases reduce hydrogen peroxide to water and reduced glutathione and lipid hydroperoxides to their corresponding alcohols, water and reduced glutathione. Four type of GPXs have been identified: cellular GPX, gastrointestinal GPX, etracellular GPX, and phospholipid hydroperoxide GPX (Tappel, 1984). 
Glutathione reductase (GR, EC 1.8.1.7) participates on maintenance of intracellular concentration of glutathione.

Other an essential part of defence mechanism is a super-family of enzymes called glutathione transferases (GSTs, EC 2.5.1.18). These enzymes are involved in the cellular detoxification of various electrophilic xenobiotic substances such as chemical carcinogens, environmental pollutants, and antitumor agents. Glutathione transferases inactivate endogenous $\alpha, \beta$-unsaturated aldehydes, quinone, epoxides, and hydroperoxides formed as secondary metabolites during oxidative damage. GSTs may reduce reactive oxygen species to less reactive metabolites and protect organism against consequences of lipid peroxidation. Glutathione transferases are of interest to researchers because they provide targets for antiasthmatic and antitumor drug therapies (Ruscoe et al., 2001).

Glutathione (GSH, y,L-Glutamyl-L-cysteinylglycine) is an important antioxidant which reduces organic hyperoxides and protect organs from lipid peroxidation.

Heme oxygenase (heat shock protein 32, HO; EC 1.14.99.3) plays an important role in organism defence to oxidative stress (Paredi et al., 1999) and inflammation (Otterbien \& Choi, 2000). There are known tree isoforms of HO: HO-1, HO-2, and HO-3. HO-1 is activated by a lots of inflammatory mediators, reactive oxygen species and by another stimuli (proinflammatory cytokines: interleukin- $1 \beta$, interleukin- 6 , interferon- $\gamma$, tumor necrosis factor- $\alpha$, bacterial toxins; airway viral infection; heme; hemin; reactive oxygen species: superoxide, peroxynitrite, hydrogen peroxide and reactive nitrogen species) (Nath et al., 2001; Sardana et al., 1981). HO-1 is expresses mainly in epithelial cells and endothelial cells of air system (Paredi et al., 1999).

Although cells possess complex net of antioxidant defence, the defence is not completely effective. Small fractions of oxidants escape from elimination and cause molecular damage. Some of these damages are irreversible therefore they are accumulated in time and they make base of functional decline. At specific conditions production of reactive oxygen species is increased and thereby balance between reactive oxygen species and defence systems is disrupted. In consequence, imbalance between oxidants and antioxidants in favour of oxidants and their harmful effects, oxidative damage is increased. Oxidative damage of biomolecules is a major contributor factor to many diseases such as cardiovascular and neurological diseases, lung diseases, ischemia-reperfusion injury, cancer and cataracts (Ames at al., 1993) and to physiological processes such as ageing and protein turnover (Fukagawa, 1999; Stadtman, 1993).

\section{Bronchial asthma}

Bronchial asthma (BA) is a lung disorder characterized by inflammation and airway hyperresponsiveness. The causes and pathogenic mechanisms of BA are poorly understood, and available treatments do not reverse and stop the disease process. Bronchial asthma has a significant global impact, affecting approximately 300 million individuals worldwide. The prevalence of bronchial asthma increases significantly during past years, especially in children. Asthma has become more common in both children and adults around the world in recent decades. The increase in the prevalence of asthma has been associated with an increase in atopic sensitization, and is paralleled by similar increases in other allergic 
disorders such as eczema and rhinitis. Asthma is a complex and heterogeneous chronic inflammatory disease of airways that involves the activation of many inflammatory and structural cells, all of which release inflammatory mediators that result in the typical pathophysiological changes in asthma (Barnes at al., 1998). Bronchial asthma is characterized by recurrent episodes of airway obstruction that resolve spontaneously or as a result of treatment, which occurs in individuals who may periodically have normal airway function. The airway mucosal inflammatory response in asthma is characterized by increased vascular permeability with oedema of airway walls, mucus hypersecretion with small airway plugging and infiltration by inflammatory cells, typically eosinophils. Prominent symptoms include wheezing, breathlessness, chest tightness, and cough, particularly at night and/or early in the morning.

Asthma has been recognized as a disease since the earliest times; Hippocrates used the term " $\alpha \delta \theta \mu a$ ". The pathogenesis of BA is complicated and at present poorly understood. Asthma is a disorder involving all bronchial structures and depends on a complex interaction between the respiratory tract and inflammatory cells, mediators and adhesion molecules. Release of mediators primes both activation and migration of inflammatory cells that cause various degrees of airway obstruction, alternations in the mucociliary system and hyperreactivity o the bronchial smooth muscles. The cells infiltrating the bronchial mucosa in patients with asthma produce also reactive oxygen species (Andreadis at al., 2003). Oxidative damage plays an important role in the development of bronchial asthma. Increase production of reactive oxygen species leads to mutagenic alternations resulting in many pathological processes and can be implicated in pathogenesis of asthma.

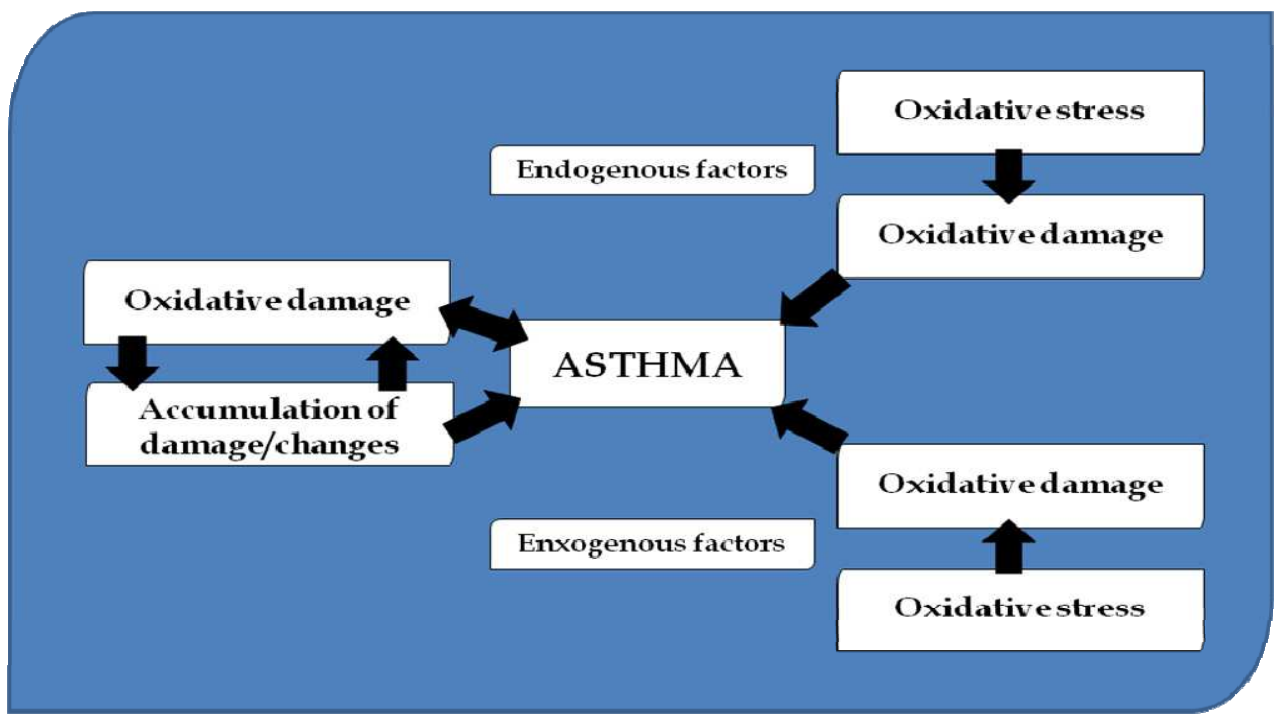

Fig. 5. Participation of oxidative damage in the bronchial asthma origin.

Protein oxidation, DNA modification and lipid peroxidation, all of these oxidative changes can be cumulated in airway and may participate to bronchial asthma persistence and lead to 
further release of mediators from epithelium resulting in further increase of oxidative damage which can again participate in asthma pathogenesis (fig. 5). Oxidative damage represents dynamic balance between a degree of oxidative damage and a degree of repair of this damage. Changes are not happened only in consequence of oxidative damage of biomolecules but also in consequence of damage of repair mechanisms.

Direct evidences of a causal role of reactive oxygen species in asthma are limited. Reactive oxygen species can influence airway cells and initiate lipid peroxidation, protein oxidation, DNA modification, enhancing release of arachidonic acid from cell membranes, contracting airway smooth muscle, increasing vascular permeability, increasing airway reactivity and airway secretion, as well as the synthesis and release of chemoattractants, inducing the release of tachykinins and neurokinins, decreasing cholinesterase and neutral endopeptidase activities, and impairing the responsiveness of $\beta$-adrenergic receptors (Barnes, 1994; Barnes et al., 1998; Rahman \& MacNee, 2002). Increased oxidative damage can contribute to the origin and development of respiratory disease including bronchial asthma.

\subsection{Oxidative damage in bronchial asthma}

Oxidative damage has myriad effects and can negatively influence metabolic pathways including amplifying the inflammatory process. Changes in levels of oxidants, antioxidants and markers of oxidative damage can be determined in bronchoalveolar lavage fluid (BAL), plasma, serum, tissue and as well as in exhaled breath condensate. Our measurements are still limited by low concentration of reactive oxygen species, their extreme reactivity and short lifetime and therefore a determination of biomarkers which can reflect existence of reactive oxygen species predominates over direct evidences of increased origin of reactive oxygen species.

The ability to collect and analyse exhaled condensate has allowed the direct assessment of reactive oxygen species in allergic respiratory diseases. Higher concentration of hydrogen peroxide (Emelyanov et al., 2001; Horvath et al., 1998), superoxide anion radical (Jarjour \& Calhoun, 1994; Sedgwick et al., 1990; Teramoto et al., 1996), nitric oxide (Ashutosh, 2000; Banovcin et al., 2009) was observed in asthmatic patients. Data about normal physiological value of ROS and oxidative damage biomarkers of DNA, proteins and lipids are missing or very rare in adults or in children population and therefore an implication of relevant conclusion can be uncertain.

\subsubsection{Protein oxidative damage}

A prominent marker of oxidative damage is oxidative damage of proteins. Endogenous proteins are very sensitive to modification by reactive oxygen species. Oxidized proteins can loss their biological function as result of extensive complex protein chemical modifications. These proteins may be changed to proteins which are more sensitive to intracellular proteolysis (Davies, 1987) and are very quickly degraded by endogenous proteases (Stadtman \& Bertlet, 1997). Protein oxidation by reactive oxygen species may lead to oxidation of side chains of amino acids residues and proteins can contain new functional groups (hydroxyl and carbonyl groups) (Fu et al., 1998), to cleavage of peptide bounds, to form new protein-protein cross bounds (Stadtman \& Berlett, 1997). These changes can result in secondary modifications such as protein fragmentation, aggregation, unfolding 
(Davies, 1987) whereby these processes are connected with change or loss protein activity and protein function (Stadtman, 1993). Children with bronchial asthma had higher level of protein carbonyls compared to the healthy children (Szlagatys-Sidorkiewicz et al., 2005). There was observed a trend for higher concentrations in protein carbonyls in atopic asthmatic children compared with control subjects (Schock et al., 2003). Increased level of protein carbonyls was observed also in BAL of atopic asthmatic children (Foreman et al., 1999). We observed plasma protein modification in our group of asthmatic children (Babusikova et al., 2009). The total concentration of sulfhydryl groups was decreased during asthma. The value was lower in asthmatic group of children compared to the healthy subjects. Asthmatic patients with atopy had significantly lower amount of sulfhydryl groups than non-atopic patients. Nadeem et al. (2005) observed significant different in total sulfhydryl groups content between acute and stable asthmatics. Buss et al. (2003) observed 3-chlorotyrosine in tracheal aspirate in significantly higher amounts in preterm infants with respiratory distress than in control infants. Nitrotyrosine was increased in exhaled breath condensate in patients with mild asthma (Hanazawa et al., 2000), in children (Baraldi et al., 2006) and in airway epithelial lining fluid of asthmatic children (Fitzpatrick et al. 2009).

In asthmatic children was observed increased level of eosinophils and mast cells compared to the healthy children (Schock et al., 2003). Several studies observed an increased level of eosinophils in adults with bronchial asthma in peripheral blood, in tissues and in exhaled breath condensate (Venge, 1995; 2010). In asthmatic children, the number of inflammatory cells in BAL fluid correlated significantly with the concentration of protein carbonyls (Schock et al., 2003). Increased respiratory burst can reflect increased oxidative stress, phagocyte auto-oxidation and subsequent intracellular oxidant release leading to additional inflammatory and lung damage in asthmatic children. Tissue damage and phagocyte activation can contribute to increased reactive oxygen species production. Activated phagocyte, neutrophils, eosinophils, monocytes and macrophage generate large amount of superoxide anion radical.

\subsubsection{Lipid peroxidation}

Lipid peroxidation is example of oxidative damage of biological membranes, lipoproteins and another lipid containing structures. It can be a very destructive process in a living system. Damaged biological membranes have changed biophysical properties. Proteins and lipids have limited mobility in membrane and membrane fluidity is decreased (Kaplan et al., 2003). Peroxidation of membrane lipids leads to the production of isoprostanes. Isoprostanes are chemical stable substances and they can contribute to the pathophysiological changes seen in asthma. They are generated in vivo and are specific for lipid peroxidation (Praticò et al., 2001). Increased level of 8-isoprostanes was observed in exhaled breath condensate (Baraldi et al., 2003; Caballero Balanza et al., 2010; Montuschi et al., 1999), in plasma (Wood et al., 2000), as well as in urine and BAL (Dworski et al., 1999) of asthmatic patients. Ethane can reflect changes that are happened in consequence of lipid peroxidation (Kneepkens et al., 1994). Increased level of ethane which is produced following lipid peroxidation in exhaled breath was observed in adult with bronchial asthma (Paredi et al., 2000). Other markers of lipid peroxidation are thiobarbituric acid-reactive substances (TBARS) measuring the concentration of malondialdehyde, an end product of the oxidation of polyunsaturated fatty acids. Oxidative stress can cause accumulation of TBARS. We 
observed increased levels of hiobarbituric acid-reactive substances in asthmatic children (Babusikova et al., 2009). Concentration of TBARS was significantly higher in exacerbated asthmatic children compared to controlled asthmatics and in atopic children levels of thiobarbituric acid-reactive substances enhanced compared to non-atopic as well. Increased level of TBARS was observed also in exhaled breath of asthmatic patients (Antczak et al., 1997) and in plasma of asthmatic patients (Shanmugasundarasn et al., 2001). Concentration of malondialdehyde was higher in exhaled breath condensate in asthmatic children (Corradi et al., 2003, Kalayci et al., 2000). Increased level of malondialdehyde was observed also in BAL and peripheral blood sample of adult patients (Ozaras $R$ et al., 2000).

\subsubsection{Antioxidant changes}

Antioxidant deficiencies have been frequently reported in patients with BA. The data are inconsistent, possibly due to variation in disease severity, diet, and ethnic, using techniques and using human fluids for measurement. Activities of enzymatic antioxidants have been reported increased, decreased, and unchanged as well. In children with asthma was observed increased activity of superoxide dismutase in erythrocytes and serum (Liao et al., 2004; Szlagatys-Sidorkiewicz et al., 2005). Decreased and unchanged levels of antioxidant enzymes such as superoxide dismutase, catalase and glutathione peroxidase were observed (Comhair et al., 2000; Novak et al., 1991; Powell et al., 1994; Shanmugasundarasn et al., 2001). Decreased activity of salivary peroxidase was found in children (Bentur et al., 2006). Total antioxidant capacity in serum of asthmatic children was decreased (Liao et al., 2004). Asthmatic patients with severe exacerbation of their disease have decreased serum total antioxidant status (Katsoulis et al., 2003). Concentration of glutathione peroxidase was not changed in asthmatic children (Marcal et al., 2004). Glutathione transferase shared catalytic properties for reaction of glutathione with reactive substrates. GST enzyme family is critical for protecting cells from reactive oxygen species because enzymes can utilize a wide range of products of oxidative damage as substrates. Members of glutathione transferase superfamily play an important role in the lungs during various physiological and pathophysiological conditions (Gilliland et al., 2002a, b, c). Peripheral blood lymphocyte glutathione concentration may potentially serve as a convenient marker of lung inflammation. The increase demand for glutathione production in the face of ongoing inflammation suggests a potential role for supplementation with cysteine donors (Lands et al., 1999). GSTM1 can be an important susceptibility factor for children with bronchial asthma after exposure during the fetal period (Gilliland et al., 2002a). Polymorphism within GSTP1 does not represent a major genetic factor in the development of bronchial asthma in children (Nickel et al., 2005). Variants of glutathione transferase confer risk to the development of asthma when the children are exposed to smoke (Kabesh et al., 2004). A significant decreased level of a-tocopherol, $\beta$-carotene, and ascorbic acid was detected in serum and erythrocytes of asthmatic children (Shanmugasundarasn et al., 2001; Kalayci et al., 2000). Composition of diet can also contribute to the increased development of bronchial asthma. Pulmonary functions are affected by intake of fresh fruit. Low intake of fruit rich in vitamin $\mathrm{C}$ is associated with an increased frequency of wheezing symptoms in children. Lung function parameters were lower in children with inadequate antioxidant vitamin intake (Gilliland et al., 2003). Decreased concentration of vitamins can suggest imbalance between antioxidant/oxidant status and it can be related with chronic airflow limitation. Diets and oxidative stress play a role in adults (Ochs-Balcom et al., 2006). Changes in 
antioxidant-oxidant balance in BAL fluid in children with asthma may be an indicator of ongoing inflammatory event in symptom-free periods. This inflammation is associated with the increased production of reactive oxygen species or oxidative stress in lung.

Individual parameters of oxidative damage influence reciprocally and together participate in the development of bronchial asthma (fig. 6). Estimation of all kind of markers of oxidative damage (proteins, lipids, DNA), together with estimation of antioxidant defence status, production of reactive oxygen species and genotype of relevant genes in the same time in asthmatic patients can be helpful for the selection the best treatment.

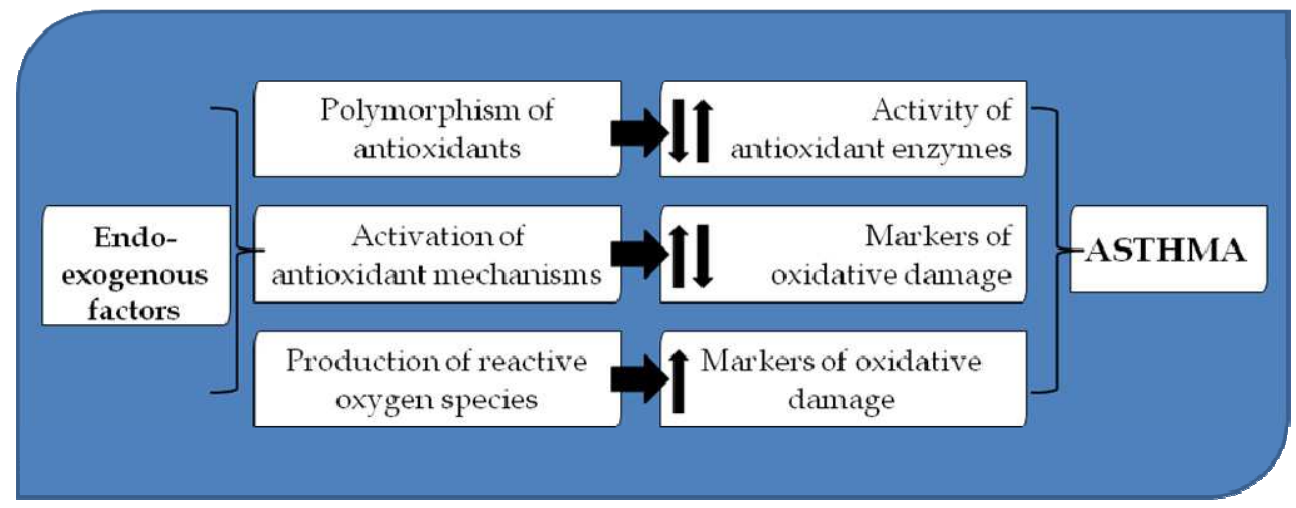

Fig. 6. Participation of oxidative damage factors in origin of bronchial asthma. Oxidative damage results from polymorphism of antioxidant genes (influencing enzyme activity), activation of antioxidant pathways, and polymorphism of prooxidant genes and production of reactive oxygen species (influencing increased oxidative damage).

\subsubsection{Genetic changes in bronchial asthma related to oxidative damage}

Environmental and genetic factors play a role in the development of asthma; however, the exact mechanisms of these factors are not fully determined. A prominent aim of BA research is to understand the genetic and environmental triggers for bronchial asthma. Asthma clusters in families and twin studies suggest a strong genetic component to bronchial asthma. Having a parent with asthma doubles a child's risk of asthma, and having two affected parents increases the risk 4-fold (Gilliland et al., 2001). Many genes as well as genegene interactions are associated with asthma (fig. 7).

Superoxide dismutase represents the most important part of an active antioxidant defence. Since superoxide dismutase is decreased in asthma, and its activity is strongly related to BA pathophysiology, it has been hypothesized that genetic variations in superoxide dismutase may play a role in the development of asthma. The genes encoding SOD1, SOD2, SOD3 are located in different chromosomes and in all of them polymorphisms have been described. SOD1 is encoded on 21q22.1, SOD2 on 6q25.3, and SOD3 on 4p16.3-q21. Regulation of SOD genes plays a crucial role in balancing the reactive oxygen species concentration. In SOD1 has been observed substitution of $\mathrm{A}$ to $\mathrm{C}$ at the non-coding position 35 . This polymorphism influence SOD1 activity (Flekac et al., 2008). Substitution $\mathrm{T}$ to $\mathrm{C}$ at position 24, resulting in a 
valine to alanine substitution at amino acid 16 has been identified in SOD2. Impairment of the mitochondrial superoxide dismutase activity was related to bronchial asthma pathophysiology (Comhair et al., 2005). In SOD3 gene has been identified three single nucleotide polymorphism: alanine to threonine substitution at amino acid 40, phenylalanine to cysteine at amino acid 131, and finally the most studied polymorphism which represents substitution of arginine to glycine at amino acid 213. Studies about superoxide dismutase polymorphisms are very rare in asthmatic population. In Chinese and Finnish asthmatic patients was not found significant differences either in allele or in genotype in SOD2 (Kinnula et al., 2004; Mak et al., 2006).

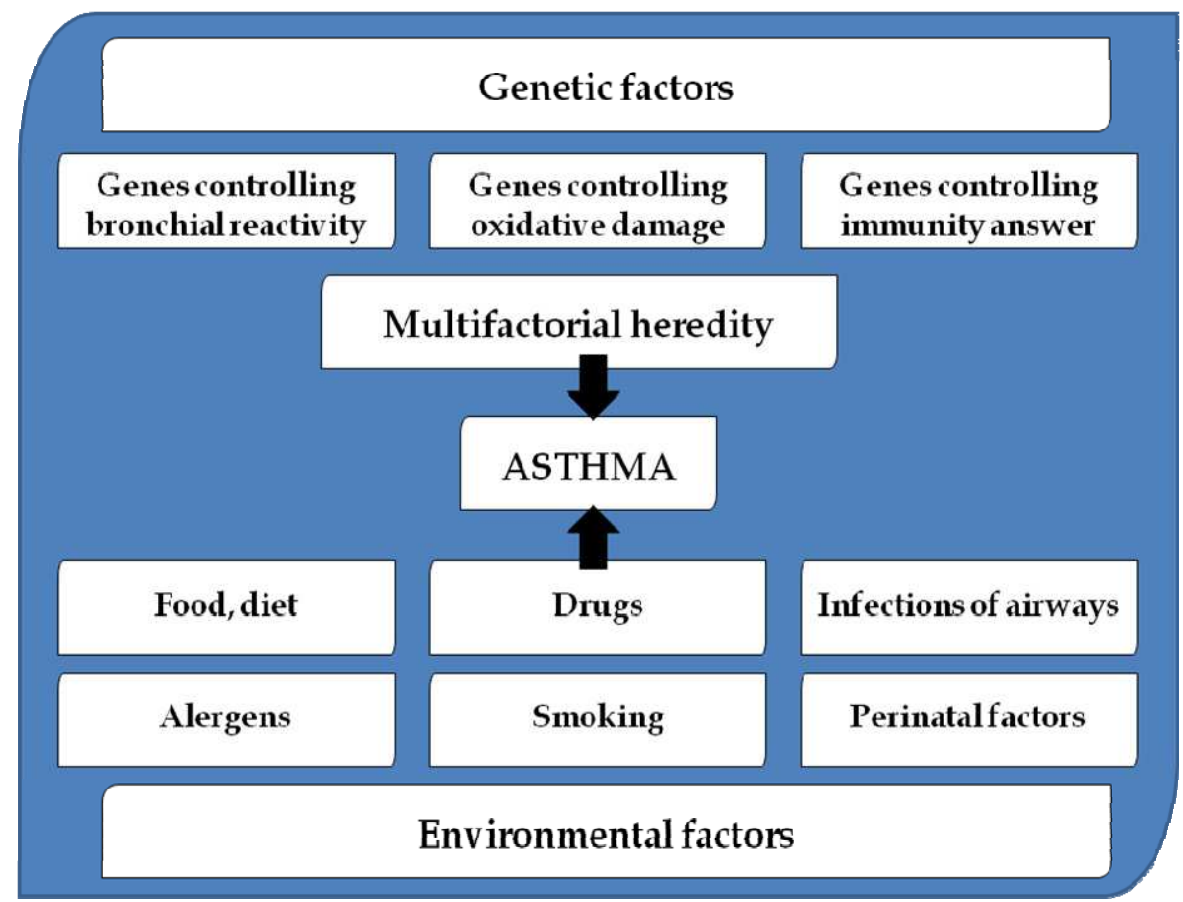

Fig. 7. Impact of genetic and environmental factors on bronchial asthma development.

Catalase is a common antioxidant enzyme responsible for controlling hydrogen peroxide concentrations in cells. The catalase gene is located on chromosome 11p13. There are known different polymorphisms of this enzyme in coding regions (Goth, 1998; Kishimoto et al., 1992) and in non-coding regions as well (Casp et al., 2002; Forsberg et al., 2001; Goth et al., 2005; Kishimoto et al., 1992; Ukkola et al., 2001; Zhou et al., 2005; Wen et al., 1990). A common polymorphism in the promoter region of the catalase gene consists of a $\mathrm{C}$ to $\mathrm{T}$ substitution at position -262 in the $5^{\prime}$ region (Forsberg et al., 2001), which is thought to result in reduced activity. CAT polymorphism may be associated with increased risk of asthma (Mak et al., 2006; Polonikov et al., 2009). In our study the frequency of TT genotype of catalase $-262 \mathrm{C} \rightarrow \mathrm{T}$ was 0.226 in asthmatic children and 0.048 in healthy children $(p<0.001)$ and CAT polymorphism may be associated with increased oxidative damage in asthmatic subjects (unpublished results). 
Glutathione transferase genes have been suggested as candidate genes for BA because they are involved in antioxidant defence pathways and they are expressed in the lungs. Glutathione transferases have historically also been called glutathione-S-transferases, and it is this latter name that gives rise to the widely used abbrevation, GST. Three major families of proteins the cytosolic, mitochondrial and microsomal (membrane-associated proteins in eicosanoids and glutathione metabolism, MAPEG) are known. In some organisms expression of GSTs are upregulated by exposure to prooxidants (An \& Blackwell, 2003; Desikan et al., 2001; Veal et al., 2002). Seven classes of cytosolic glutathione transferases are recognising in mammals (Alpha, Mu, Pi, Sigma, Theta, Omega, and Zeta) (Hayes \& Pulford, 1995). At least 16 cytosolic GST subunits exists in human and display polymorphisms, and this is probably contributing factor to interindividual differences in responses to diseases and xenobiotics. GSTM1 is one of the genes encoding the Mu class of enzymes. Gene for GSTM1 has been mapped to glutathione transferase mu gene cluster on chromosome 1p13.3. Three polymorphisms of GSTM1 have been identified: a substitution (GSTM1A and GSTM1B) and a deletion (Rebbeck, 1997; Xu et al., 1998). The alleles of the substitution variant differ by $C$ to $G$ transition at base position 534, resulting in a lysine to asparagine substitution at amino acid 172 (Cotton et al., 2000; Rebbeck, 1997). There is no evidence to date that GSTM1A and GSTM1B alleles are functionally different from one another; thus these alleles are typically categorized together as a single functional phenotype. Other polymorphism is a deletion - GSTM1 null variant that results in a lack of functional gene product. The GSTT1 gene is located at 22q11.2. Absence of both alleles for this gene represents null variant analogous to GSTM1. Deletion of whole gene results in the lack of enzymatic activity (Sprenger et al., 2000). Gene for GSTP1 is one of the most intensive studying genes of glutathione transferase family and has been mapped on chromosome $11 \mathrm{q} 13$ and comprising nine exons. There are known two polymorphisms of GSTP1: substitution of isoleucine to valine at amino acid 105 and alanine to valine at amino acid 114, demonstrating different catalytic efficiencies due to changes in the active site (Ali-Osman et al., 1997). A number of studies suggest that GSTM1, GSTT1, GSTM1 polymorphisms increase susceptibility to asthma (Babusikova et al., 2009; Hanene et al., 2007; Kamada et al., 2007; Romieu et al., 2006; Tamer et al., 2004). GSTM1 and GSTT1 deficiency may increase the risk for the asthma development of in utero and current smoke exposure (Kabesch et al., 2004). People with a GSTM1 null variant or GSTP1 Val/Val genotype show decreased in lung function growth (Gilliland et al., 2002b; Imboden et al., 2007).

Nicotinamide adenine dinucleotide (phosphate) reduced:quinone oxidoreductase (NQO1, EC 1.6.5.2) is phase II enzyme important in response to oxidative stress. NQO1 is highly expressed in the lungs. The gene for this protein is localised on chromosome 16q22.1. NQO1 catalyzes the two-electron reduction of quinones to hydroquinones, thus bypassing the potentially toxic semiquinone radical intermediate (Jaiswal, 2000; Vasiliou et al., 2006) and prevents the generation of reactive oxygen species, and protects cells from oxidative damage. Some evidence suggest that NQO1 may also interact directly with reactive oxygen species (Jia et al., 2008), such as hydroxyl radical and hydrogen peroxide, and may influence the balance between oxidants and antioxidants. This enzyme can act also as an antioxidant enzyme by reducing ubiquinone (coenzyme $\mathrm{Q}_{10}$ ) and vitamin E quinone to their antioxidant forms (Beyer et al., 1996; Siegel et al., 1997) and bases on its influence on antioxidant mechanisms NQO1 is a candidate gene. Currently, there are 22 reported single-nucleotide 
polymorphisms in the NQO1 gene. Only two of these, arginine139tryptophan and proline187serine (Larson et al., 1999; Traver et al., 1992) have been studied extensively. The NQO1 gene plays an important role in asthma susceptibility (David et al., 2003; Li et al., 2009). Functional polymorphism of NQO1 gene with conjugation of GSTM1 null variant can have a protective effect in relation to asthma risk (David et al., 2003). For individuals already exhibiting disease status, a decrease or loss of NQO1 activity due to mutation, can play a role by increasing the risk of severity (Goodrich et al., 2009). Polymorphism in NQO1 gene may be an important factor determining the intensity of medical therapy in asthmatic children. Asthmatic children with functional polymorphism of NQO1 may require more intensive pharmaceutical treatment to effectively control their asthma (Goodrich et al., 2009).

Nicotinamide adenine dinucleotide phosphate oxidase (NADPH oxidase, EC 1.6.3.1) is a membrane-associated enzyme that catalyzes the production of superoxide anion. This enzyme is one of the main sources of superoxide anion and is highly expressed in neutrophils and endothelial cells (Azumi et al., 1999). NADPH oxidase is multicomponent enzyme made up from six subunits: Rho guanosine triphosphatase and five subunits of phagocytic oxidases (phox). Gp91phox and gp22phox are transmembrane subunits, and p40phox, p47phox and p67phox are cytosol subunits. The gp22phox is also called cytochrome $b$ a subunit (CYBA) and presence of this protein in the NADPH oxidase determines the enzyme activity and production of superoxide radical (De Keluelanear et al., 1999). There were identified three polymorphisms in gene for gp22phox subunit at position +242 in exon 4 , which consists of a $C$ to $\mathrm{T}$ substitution resulting in a histidine to tyrosine substitution at amino acid 72; in the $3^{\prime}$ untranslated region at position $640 \mathrm{~A}$ is substituted by $\mathrm{G}$, and the third polymorphism is located in the promoter region at position -930 , which consists of a A to G substitution (Dinauer et al., 1990; Moreno et al., 2003). Polymorphism of CYBA can be an important genetic component that determines susceptibility to allergic form of BA (Ivanov et al., 2008).

\subsubsection{Antioxidant treatment}

Antioxidant therapy may be a useful treatment for bronchial asthma because oxidative damage is increased in asthmatic patients. Epidemiological studies suggest that antioxidant have a significant effect on the incidence and severity of BA (Fogarty \& Britton, 2000; Smith et al., 1999). There are several antioxidants, including endogenous metobolites (glutathione, $\mathrm{N}$-actylcysteine, heme oxygenase 1 , uric acid), natural antioxidants and other nutrients (vitamins C and E, $\beta$-carotene, co-enzyme Q10, urate, curcumin, a lipoic acid, fish oil), and herbal molecules and polyphenols (esculitin, sulforaphane, resveratrol, caffeic acid phenethyl ester). Vitamin C and E are powerful antioxidants found in the lungs. Vitamin C is hydrophilic antioxidant and acts to quench radicals within cells and regenerates vitamin E. Vitamin E is a lipophilic chain-breaking antioxidant that acts by stopping the chain reaction involved in lipid peroxidation. Urate is hydrophilic and has chain-breaking properties and stabilizes vitamin $\mathrm{C}$ as well. Several authors observed decreased oxidative damage in asthmatic mice treated with antioxidants (Dittrich et al., 2009; Lee et al., 2009; Okamoto et al., 2006). Studies of antioxidant intake have provided conflicting results in asthmatic patients. Epidemiological studies indicate that elevated dietary intake of vitamin C may be associated with a reduced risk of asthma (Hatch, 1995; Soutar et al., 1997). On the 
other hand, many studies do not indicate any relation between asthma and vitamin C (Fogarty et al., 2003; Troisi et al., 1995). Pearson et al. (2004) observed no benefit of dietary supplementation with vitamin $\mathrm{E}$ in adults with mild to moderate asthma. Controlled studies in humans, on both healthy subjects (Chatham et al., 1987; Samet et al., 2001) and individuals with asthma (Trenga et al., 2001), have also suggested that antioxidant supplementation (vitamin $\mathrm{C}$ and vitamin $\mathrm{E}$ ) may protect against the acute effects of ozone on lung functioning. Supplementation with antioxidants might modulate the impact of ozone exposure on the small airways of children with moderate to severe asthma (Romieu et al., 2002). Vitamin A supplementation early in life was not associated with a decreased risk of asthma in an area with chronic vitamin A deficiency (Checkley et al., 2011). Diet supplementation with omega-3 fatty acids, $\mathrm{Zn}$ and vitamin $\mathrm{C}$ significantly improved asthma control test, pulmonary function tests and pulmonary inflammatory markers in children with moderately persistent bronchial asthma either singly or in combination (Biltagi et al., 2009). Dietary supplementation with vitamins $E$ and $C$ benefits asthmatic adults who are exposed to air pollutants (Trenga et al., 2001).

\section{Conclusion}

Prevalence of bronchial asthma increases and represents very serious medical problems. Bronchial asthma is a complex multifactorial disease in which environmental factors, oxidative damage and genetic factors are responsible for initiating and modulating the progression of the disease. Several markers of oxidative damage in plasma, serum, exhaled breath, and as well as in bronchoalveolar lavage fluid are rising in patients with asthma. Oxidative damage represents an important factor contributing to the origin and persistence of airway inflammation in asthmatic subjects. The role of mentioned gene polymorphisms and many others gene polymorphisms as risk factors for the occurrence of bronchial asthma is still controversial. We still need new studies for clear determination gene polymorphisms which are related to asthma. Moreover multiple genotype analyses are necessary as well because a single gene polymorphism can be without relationship to increased risk of asthma but the combination of gene polymorphisms may have a significant effect for asthma development. Oxidative damage plays a significant role in the pathology of bronchial asthma therefore this process may represent a potential target of the therapy in asthmatic patients. In summary bronchial asthma is a no single disease; it is an umbrella of diseases associated with increased oxidative stress followed by an accumulation of oxidative damage.

\section{Acknowledgment}

This work was supported by grants VEGA 1/0071/11 and Ministry of Health 2007/47-UK12.

\section{References}

Ali-Osman, F., Akande, O., Antoun, G., Mao, .JX. \& Buolamwini, J. (1997). Molecular cloning, characterization, and expression in Escherichia coli of full-length cDNAs of three human glutathione S-transferase Pi gene variants. Evidence for differential 
catalytic activity of the encoded proteins. The Journal of Biological Chemistry, Vol.272, No.15, (April 1998), pp. 10004-10012

Ames, B. N., Shigenaga, M. K. \& Hagen, T. M. (1993). Oxidants, antioxidants, and the degenerative diseases of aging. Proceedings of the National Acadademy of the Sciences of the United States of America, Vol.90, No.17, (September 1993), pp. 7915-7922

An, J.H. \& Blackwell, T.K. (2003). SKN-1 links C. elegans mesendodermal specification to a conserved oxidative stress response. Genes and Development, Vol.17, No.15, (August 2003), pp. 1882-1893

Andreadis, A.A., Hazen, S.L., Comhair, S.A. \& Erzurum, S.C. (2003). Oxidative and nitrosative events in asthma. Free Radical Biology and Medicine, Vol.35, No.3, (August 2003), pp. 213-225

Antczak, A., Nowak, D., Shariati, B., Król, M., Piasecka, G. \& Kurmanowska Z. (1997). Increased hydrogen peroxide and thiobarbituric acid-reactive products in expired breath condensate of asthmatic patients. The European Respiratory Journal, Vol.10, No.6, (June 1997), pp. 1235-1241

Ashutosh, K. (2000). Nitric oxide and asthma: a review. Current Opinion in Pulmonary Medicine, Vol.6, No.1, (January 2000), pp. 21-25

Azumi, H., Inoue, N., Takeshita, S., Rikitake, Y., Kawashima, S., Hayashi, Y., Itoh, H. \& Yokoyama, M. (1999). Expression of NADH/NADPH oxidase p22phox in human coronary arteries. Circulation, Vol.100, No.14, (October 1999), pp. 1494-1498

Babusikova, E., Jesenak, M., Kirschnerova, R., Banovcin, P. \& Dobrota D. (2009). Association of oxidative stress and GST-T1 gene with childhood bronchial asthma. Journal of Physiology and Pharmacology, Vol.60, No.Suppl. 5, (November 2009), pp. 27-30

Banovcin, P., Jesenak, M., Michnova, Z., Babusikova, E., Nosal, S., Mikler, J., Fabry, J. \& Barreto M. (2009). Factors attributable to the levels of exhaled nitric oxide in asthmatic children. European Journal of Medical Research, Vol.14, Suppl. 4, (December 2009), pp. 9-13

Baraldi, E., Ghiro, L., Piovan, V., Carraro, S., Ciabattoni, G., Barnes, P.J. \& Montuschi P. (2003). Increased exhaled 8-isooprostane in childhood asthma. Chest, Vol.124, No.1, (July 2003), pp. 25-31

Baraldi, E., Giordano, G., Pasquale, M.F., Carraro, S., Mardegan, A., Bonetto, G., Bastardo, C., Zacchello F. \& Zanconato, S. (2006). 3-Nitrotyrosine, a marker of nitrosative stress, is increased in breath condensate of allergic asthmatic children. Allergy, Vol.61, No.1, (January 2006), pp. 90-96

Barnes, P.J. (1994). Cytokines as mediators of chronic asthma. American Journal of Respiratory and Critical Care Medicine, Vol.150, No.5Pt2, (November 1994), pp. S42-S49

Barnes, P.J., Chung, K.F., \& Page C.P. (1998). Inflammatory mediators of asthma: an update. Pharmacological Reviews, Vol.50, No.4, (December 1998), pp. 515-596

Beckman, K. B. \& Ames, B. N. (1998). The free radical theory of aging matures. Physiological Review, Vol.78, No.2, (April 1998), pp. 547-581

Bentur, L., Mansour, Y., Brik, R., Eizenberg, Y. \& Nagler R.M. (2006). Salivary oxidative stress in children during acute asthmatic attack and during remission. Respiratory Medicine, Vol.100, No.7, (July 2006), pp. 1195-1201

Bergendi, L., Benes, L., Durackova, Z. \& Ferencik, M. (1999). Chemistry, physiology and pathology of free radicals. Life Sciences, Vol.65, No.18-19, pp. 1865-1874 
Beyer, R.E., Segura-Aguilar, J., Di Bernardo, S., Cavazzoni, M., Fato, R., Fiorentini, D., Galli, M.C., Setti, M., Landi, L. \& Lenaz, G. (1996). The role of DT-diaphorase in the maintenance of the reduced antioxidant form of coenzyme $Q$ in membrane systems. Proceedings of the National Acadademy of the Sciences of the United States of America, Vol.93, No.6, (March 1996), pp. 2528-2532

Biltagi, M.A., Baset, A.A., Bassiouny, M., Kasrawi, M.A. \& Attia, M. (2009). Omega-3 fatty acids, vitamin $\mathrm{C}$ and $\mathrm{Zn}$ supplementation in asthmatic children: a randomized selfcontrolled study. Acta Paediatrica, Vol.98, No.4, (April 2009), pp. 737-742

Buss, I.H., Senthilmohan, R., Darlow, B.A., Mogridge, N., Kettle, A.J. \& Winterbourn C.C. (2003). 3-Chlorotyrosine as a marker of protein damage by myeloperoxidase in tracheal aspirates from preterm infants: association with adverse respiratory outcome. Pediatric Research, Vol.53, No.3, (March 2003), pp. 455-462, Erratum in: Pediatric Research, Vol.53, No.5, (May 2003), pp. 868

Caballero Balanzá, S., Martorell Aragonés, A., Cerdá Mir, J.C., Ramírez, J.B., Navarro, Iváñez, R., Navarro Soriano, A., Félix Toledo, R. \& Escribano Montaner A. (2010). Leukotriene B4 and 8-isorostane in exhaled breath condensate of children with episodic and persistent asthma. Journal of Investigational Allergology and Clinical Immunology, Vol.20, No.3, pp. 237-243

Casp, C.B., She, J.X. \& McCormack, W.T. (2002). Genetic association of the catalase gene (CAT) with vitiligo susceptibility. Pigment Cell Research, Vol.15, No.1, (February 2002), pp. $62-66$

Chan, P. H. (2001). Reactive oxygen radicals in signaling and damage in the ischemic brain. Journal of Cerebral Blood Flow and Metab.olism, Vol.21, No.1, (January 2001), pp. 2-14

Chatham, M.D., Eppler, J.H. Jr,, Saunder, L.R., Green, D. \& Kulle, T.J. (1987). Evaluation of the effects of vitamin $C$ on ozone induced bronchoconstriction in normal subjects. Annals of the New York Academy of Sciences, Vol.498, (1987), pp. 269-279

Checkley, W., West, K.P. Jr,, Wise. R,A., Wu, L., Leclerq, S.C., Khatry, S., Katz, J., Christian, P., Tielsch, J.M. \& Sommer, A. (2011). Supplementation with vitamin A early in life and subsequent risk of asthma. The European Respiratory Journal, (June 2011), Epub ahead of print

Comhair, S.A., Bhathena, P.R., Dweik, R.A., Kavuru, M. \& Erzurum, S.C. (2000). Rapid loss of superoxide dismutase activity during antigen-induced asthmatic responce, Lacent, Vol.355, No.9204, (February 2000), pp. 624

Comhair, S.A., Xu, W., Ghosh, S., Thunnissen, F.B., Almasan, A,, Calhoun, W.J., Janocha, A.J., Zheng, L., Hazen, S.L. \&Erzurum, S.C. (2005). Superoxide dismutase inactivation in pathophysiology of asthmatic airway remodeling and reactivity. The American Journal of Pathology, Vol.166, No.3, (March 2005), pp. 663-674

Corradi, M., Folesani, G., Andreoli, R., Manini, P., Bodini, A., Piacentini, G., Carraro, S., Zanconato, S. \& Baraldi E. (2003). Aldehydes and glutathione in exhaled breath condensate of children with asthma exacerbation. American Journal of Respiratory and Critical Care Medicine, Vol.167, No.3, (February 2003), pp. 395-399

Cotton, S.C., Sharp, L., Little, J. \& Brockton, N. (2000). Glutathione S-transferase polymorphisms and colorectal cancer: a HuGE review. American Journal of Epidemiology, Vol.151, No.1, (January 2000), pp. 7-32

David, G.L., Romieu, I., Sienra-Monge, J.J., Collins, W.J., Ramirez-Aguilar, M., del RioNavarro, B.E., Reyes-Ruiz, N.I., Morris, R.W., Marzec, J.M. \& London, S.J. (2003). 
Nicotinamide adenine dinucleotide (phosphate) reduced:quinone oxidoreductase and glutathione S-transferase M1 polymorphisms and childhood asthma. American Journal of Respiratory and Critical Care Medicine, Vol.168, No.10, (November 2003), pp. 1199-1204

Davies, K. J. (1987). Protein damage and degeneration by oxygen radicals. The Journal of Biological Chemistry, Vol.262, No.20, (July 1987), pp. 9895-9901

De Keulenaer, G.W., Alexander, R.W., Ushio-Fukai, M., Ishizaka, N. \& Griendling, K.K. (1998). Tumor necrosis factor alpha activities a p22phox based NADPH oxidase in vascular smooth muscle. The Biochemical Journal, Vol.329, No.Pt.3, (February 1998). pp. 653-657

Desikan, R., A-H-Mackerness, S., Hancock, J.T. \& Neill, S.J. (2001). Regulation of the Arabidopsis trancriptome by oxidative stress. Plant Physiology, Vol.127, No.1, (September 2001), pp. 159-172

Dhalla, N. S., Temsah, R. M. \& Netticadan, T. (2000). Role of oxidative stress in cardiovascular diseases. Journal of Hypertension, Vol.18, No.6, (June 2000), pp. 655673

Dinauer ,M.C., Pierce, E.A., Bruns, G.A., Curnutte, J.T. \& Orkin, S.H. (1990). Human neutrophil cytochrome b light chain (p22-Phox): gene structure, chromosomal location, and mutations in cytochrome-negative autosomal recesive chronic granulomatous disease. The Journal of Clinical Investigation, Vol.86, No.5, (November 1990), pp. 1729-1737

Dittrich, A.M., Meyer, H.A., Krokowski, M., Quarcoo, D., Ahrens, B., Kube, S.M., Witzenrath, M., Esworthy, R.S., Chu, F.F. \& Hamelmann, E. (2009). Glutathione peroxidase-2 protects from allergen-induced airway inflammation in mice. The European Respiratory Journal, Vol.35, No.5, (May 2009), pp. 1148-1154

Dworski, R., Murray, J.J., Roberts, L.J. 2nd, Oates, J.A., Morrow, J.D., Fisher, L. \& Sheller, J.R. (1999). Allergen-induced synthesis of $\mathrm{F}(2)$-isoprostanes in atopic asthmatics. Evidence for oxidant stress. American Journal of Respiratory and Critical Care Medicine, Vol.160, Vol.6, (December 1999), pp. 1947-1951

Emelyanov, A., Fedoseev, G., Abulimity, A., Rudinski, K., Fedoulov, A., Karabanov, A. \& Barnes P.J. (2001). Elevated concentrations of exhaled hydrogen peroxide in asthmatic patients. Chest. Vol.120, No.4, (October 2001), pp. 1136-1139

Fitzpatrick, A.M., Brown, L.A., Holguin, F. \& Teague W.G. (2009). Levels of nitric oxide oxidation products are increased in the epithelial lining fluid of children with persistent asthma. The Journal of Allergy and Clinical Immunology, Vol.124, No.5, (November 2009), pp. 990-996

Flekac, M., Skrha, J., Hilgertova, J., Lacinova, Z. \& Jarolimkova, M. (2008). Gene polymorphisms of superoxide dismutases and catalase in diabetes mellitus. BMC Medical Genetics, Vol.9,No.30 (April 2008)

Fogarty, A \& Britton, J. (2000). The role of diet in the eatiology of asthma. Current Opinion in Pulmonary Medicine, Vol.30, No.5, (May 2000), pp. 615-627

Fogarty, A., Lewis, S.A., Scrivener, S.L., Antoniak, M., Pacey, S., Pringle, M. \& Britton, J. (2003). Oral magnesium and vitamin $C$ supplements in asthma: a parallel group randomized placebo-controlled trial. Clinical and Experimental Allergy, Vol33, No.10, (October 2003), pp. 1355-1359 
Foreman, R.C., Mercer, P.F., Kroegel, C. \& Warner J.A. (1999). Role of the eosinophil in protein oxidation in asthma: possible effects on proteinase/antiproteinase balance. International Archives of Allergy and Immunology, Vol.118, No.2-4, (February-April 1999), pp. 183-186

Forsberg, L., Lyrenäs, L., de Faire, U. \& Morgenstern, R. (2001). A common functional C-T substitution polymorphism in the promoter region of the human catalase gene influences transcription factor binding, reporter gene transcription and its correlated to blood catalase levels. Free Radical Biology and Medicine, Vol.30, No.5, (March 2001), pp. 500-505

Fu, S., Davies, J. \& Dean, R. T. (1998). Molecular aspects of free radical damage to proteins. In Molecular biology of free radicals in human diseases, O.I. Aruoma, B. Halliwell (eds.), pp. 29-56, OICA International: Saint Lucia, ISBN 976-8056-15-0, London UK

Fukagawa, N. K. (1999). Aging: is oxidative stress a marker or is it causal? Proceedings of the Society for Experimental Biology and Medicine, Vol.222, No.3, (December 1999), pp. 293-298

Gilliland, F.D., Berhane, K., Rappaport, E.B., Thomas, D.C., Avol, E., Gauderman, W.J., London, S.J., Margolis, H.G., McConnell, R., Islam, K.T. \& Peters, J.M. (2001). The effects of ambient air pollution on school absenteeism due to respiratory illnesses. Epidemiology, Vol.12, No.1, (January 2001), pp. 43-54

Gilliland, F.D., Berhane, K.T., Li, Y.F., Gauderman, W.J., McConnell R. \& Peters J. (2003). Children's lung function and antioxidant vitamin, fruit, juice, and vegetable intake. American Journal of Epidemiology, Vol.158, No.6, (September 2003), pp. 576-584

Gilliland, F.D., Gauderman, W.J., Vora, H., Rappaport, E. \& Dubeau, L. (2002b). Effects of glutathione-S-transferase M1, T1, and P1 on childhood lung function growth. American Journal of Respiratory ans Critical Care Medicine, Vol.166, No.5, (September 2002), pp. 710-716

Gilliland, F.D., Li, Y.F., Dubeau, L., Berhane, K., Avol, E., McConnell, R., Gauderman, W.J. \& Peters, J.M. (2002a). Effects of glutathione S-transferase M1, maternal smoking during pregnancy, and environmental tobacco smoke on asthma and wheezing in children. American Journal of Respiratory ans Critical Care Medicine, Vol.166, No.4, (August 2002), pp. 457-463

Gilliland, F.D., Rappaport, E.B., Berhane, K., Islam, T., Dubeau, L., Gauderman, W.J. \& McConnell, R. (2002c). Effects of glutathione S-transferase P1, M1, and T1 on acute respiratory illness in school children. American Journal of Respiratory ans Critical Care Medicine, Vol.166, No.3, (August 2002), pp. 346-351

Goodrich, G.G., Goodman, P.H., Budhecha, S.K. \& Pritsos, C.A. (2009). Functional polymorphism of detoxification gene NQO1 predicts intensity of empirical treatment of childhood asthma. Mutation Research, Vol.674, No.1-2, (March 2009), pp. 55-61

Góth L. (1998). Genetic heterogeneity of the 5' uncoding region of the catalase gene in Hungarian acatalasemic and hypocatalasemic subjects. Clinica Chimica Acta, Vol.271, No.1, (March 1998), pp. 73-78

Góth, L., Vitai, M., Rass, P., Sükei, E. \& Páy A. (2005). Detection of a novel familial catalase mutation (Hungarian type D) and the possible risk of inherited catalase deficiency for diabetes mellitus. Electrophoresis, Vol.26, No.9, (May 2005), pp. 1646-1649 
Halliwell, B. \& Gutteridge, J.M.C. (1999). Free radicals in biology and medicine, University Press, ISBN 0-198-50044-0, Oxford, UK

Hanafy, K. A., Krumenacker, J. S. \& Murad, F. (2001). NO, nitrotyrosine, and cyclic GMP in signal transduction. Medical Science Monitor, Vol.7, No.4, (July-August 2001), pp. 801-819

Hanazawa, T., Kharitonov, S.A. \& Barnes P.J. (2000). Increased nitrotyrosine in exhaled breath condensate of patients with asthma. American Journal of Respiratory and Critical Care Medicine, Vol.162, No.4Pt1, (October 2000), pp. 1273-1276

Hanene, C., Jihene, L., Jamel, A., Kamel, H. \& Agnès, H. (2007). Association of GST genes polymorphisms with asthma in Tunisian children. Mediators of Inflammation, Vol.2007, ID:19564

Hatch, G.E. (1995). Asthma, inhaled oxidants, and dietary anti-oxidants. The American Journal of Clinical Nutrition, Vol.61, No. 3 Suppl, (March 1995), pp. 625S-630S

Hayes, J.D. \& Pulford, D.J. (1995). The glutathione S-transferase supergene family: regulation of GST and the contribution of the isoenzymes to cancer chemoprotection and drug resistance. Critical Reviews in Biochemistry and Molecullar Biology, Vol.30, No.6, pp. 445-600

Horvath, I., Donnelly, L.E., Kiss, A., Kharitonov, S.A., Lim, S., Chung, K.F. \& Barnes P.J. (1998). Combined use of exhaled hydrogen peroxide and nitric oxide in monitoring asthma. American Journal of Respiratory and Critical Care Medicine, Vol.158, Vol.4, (October 1998), pp. 1042-1046

Imboden, M., Downs, S.H., Senn, O., Matyas, G., Brändli, O., Russi, E.W., Schindler, C., Ackermann-Liebrich, U., Berger, W., Probst-Hensch, N.M. \& SAPALDIA Team. (2007). Glutathone S-transferase genotypes modify lung function decline in the general population: SAPALDIA cohor study. Respiratory Research, Vol.8:2, (January 2007)

Ivanov, V.P., Solodilova, M.A., Polonikov, A.V., Khoroshaia, I.V., Kozhukhov, M.A. \& Panfilov, V.I. (2008). Association of C242T and A640G polymorphisms in the gene for p22phox subunit of NADPH oxidase with the risk of bronchial asthma: a pilot study. Genetika, Vol.44, No.5, (May 2008), pp. 693-701

Jaiswal, A.K. (2000). Regulation of genes encoding NAD(P)H: quinone oxidoreductases. Free Radical Biology and Medicine, Vol.29, No.3-4, (August 1994), pp. 254-262

Jarjour, N.N. \& Calhoun, W.J. (1994). Enhanced production of oxygen radicals in asthma. The Journal of Laboratory and Clinical Medicine, Vol.123, No.1, (January 1994), pp. 131136

Jia, B., Park, S.C., Lee, S., Pham, B.P., Yu, R., Le, T.L., Han, S.W., Yang, J.K., Choi, M.S., Baumeister, W. \& Cheong, G.W. (2008). Hexameric ring structure of a thermophilic archaeon NADH oxidase that produces predominantly H2O. The FEBS Journal, Vol.275, NO.21, (November 2008), pp. 5355-5366

Kabesch, M., Hoefler, C., Carr, D., Leupold, W., Weiland, S.K. \& von Mutius E. (2004). Glutathione $S$ transferase deficiency and passive smoking increase childhood asthma. Thorax, Vol.59, No.7, (July 2004), pp. 569-573

Kabesch, M., Hoefler, C., Carr, D., Leupold, W., Weiland, S.K. \& von Mutius, E. (2004). Glutathione $S$ transferase deficiency and passive smoking increase childhood asthma. Thorax, Vol.59, No.7, (July 2004), pp. 569-573 
Kalayci, O., Besler, T., Kilinç, K., Sekerel, B.E. \& Saraçlar Y. (2000). Serum levels of antioxidant vitamins (alpha tocopherol, beta carotene, and ascorbic acid) in children with bronchial asthma. The Turkish Journal of Pediatrics, Vol.42, No.1, (January-March 2000), pp. 17-21

Kamada, F., Mashimo, Y., Inoue, H., Shao, C., Hirota, T., Doi, S., Kameda, M., Fujiwara, H., Fujita, K., Enomoto, T., Sasaki, S., Endo, H., Takayanagi, R., Nakazawa, C., Morikawa, T., Morikawa, M., Miyabayashi, S., Chiba, Y., Tamura, G., Shirakawa, T., Matsubara, Y., Hata, A., Tamari, M. \& Suzuki, Y. (2007). The GSTP1 gene is a susceptibility gene for childhood asthma and the GSTM1 gene is a modifier of the GSTP1 gene. International Archives of Allergy and Immunology, Vol.144, No.4, (July 2007), pp. 275-286

Kaplan, P., Babusikova, E., Lehotsky, E. \& Dobrota, D. (2003). Free radical-induced protein modification and inhibition of Ca2+-ATPase of cardiac sarcoplasmic reticulum. Molecullar Cellular Biochemistry, Vol.248, No.1-2, (June 2003), pp. 41-47

Katsoulis, K., Kontakiotis, T., Leonardopoulos, I., Kotsovili, A., Legakis, I.N. \& Patakas D. (2003). Serum total antioxidant status in severe exacerbation of asthma: correlation with the severity of the disease. Journal of Asthma, Vol.40, No.8, (December 2003), pp. 847-854

Kinnula, V.L., Lehtonen, S., Koistinen, P., Kakko, S., Savolainen, M., Kere, J., Ollikainen, V. \& Laitinen, T. (2004). Two functional variants of the superoxide dismutase genes in Finnish families with asthma. Thorax, Vol.59, No.2, (February 2004), pp. 116-119

Kinnula, V.L., Pietarinen, P., Aalto, K., Virtanen, I. \& Raivio, K.O. (1995). Mitochondrial superoxide dismutase induction does not protect epithelial cells during oxidant exposure in vitro. The American Journal of Physiology, Vol.268, No.1Pt1, (January 1995), pp. L71-77

Kinnula, V.L., Whorton, A.R., Chang, L.Y. \& Crapo, J.D. (1992). Regulation of hydrogen peroxide generation in cultured endothelial cells. The American Journal of Respiratory cell and Molecullar biology, Vol.6, No.2, (February 1992), pp. 175-182

Kishimoto, Y., Murakami, Y., Hayashi, K., Takahara, S., Sugimura, T. \& Sekiya T. (1992). Detectionof a common mutation of the catalase gene in Japanese acatalasemic patients. Human Genetic, Vol.88, No.5, (March 1992), pp. 487-490

Kneepkens, C.M., Lepage, G. \& Roy C.C. (1994). The potential of the hydrocarbon breath test as a measure of lipid peroxidation. Free Radical Biology and Medicine, Vol.17, No.2, (August 1994), pp. 127-160

Kroncke, K. D. (2001). Cysteine-Zn2+ complexes: unique molecular switches for inducible nitric oxide synthase-derived NO. The FASEB Journal, Vol.15, No.13, (November 2001), pp. 2503-2507

Lands, L.C., Grey, V., Smountas, A.A., Kramer, V.G. \& McKenna D. (1999). Lymphocyte glutathione levels in children with cystic fibrosis. Chest, Vol.116, No.1, (July 1999), pp. 201-205

Larson, R.A., Wang, Y., Banerjee, M., Wiemels, J., Hartford, C., Le Beau, M.M. \& Smith, M.T. (1999). Prevalence of the inactivating 609C-T polymorphism in the $\mathrm{NAD}(\mathrm{P}) \mathrm{H}$ :quinone oxidoreductase (NQO1) gene in the patiens with primary and therapy-related myeloid leukemia. Blood, Vol.94, No.2, (July 1999), pp. 803-807

Lee, M., Kim, S., Kwon, O.K., Oh, S.R., Lee, H.K. \& Ahn, K. (2009). Anti-inflammatory and anti-asthmatic effects of resveratrol, a polyphenolic stilbene, in a mouse model of 
allergic asthma. International Immunopharmacology, Vol.9, No.4, (April 2009), pp. 418-424

Li, Y.F., Tseng, P.J., Lin, C.C., Hung, C.L., Lin, S.C., Su, W.C., Huang, Y.L., Sung, F.C. \& Tai, C.K. (2009). NAD $(\mathrm{P}) \mathrm{H}$ : quinone oxidoreductase 1, glutathione S-transferase M1, environmental tobacco smoke exposure, and children asthma. Mutation Research, Vol.678, No.1, (August 2009), pp. 53-58

Liao, M.F., Chen, C.C. \& Hsu M.H. (2004). Evaluation of the serum antioxidant status in asthmatic children. Acta Paediatrica Taiwan, Vol.45, No.4, (July-August 2004), pp. 213-217

Mak, J.C., Leung, H.C., Ho, S.P., Ko, F.W., Cheung, A.H., Ip, M.S. \& Chan-Yeung, M.M. (2006). Polymorphisms in manganese superoxide dismutase and catalase genes: functional study in Hong Kong Chinese asthma patients. Clinical and Experimental Allergy, Vol.36, No.4, (April 2006), pp. 440-447

Marçal, L.E., Rehder, J., Newburger, P.E. \& Condino-Neto A. (2004). Superoxide release and cellular gluthatione peroxidase activity in leukocytes from chldren with persistent asthma. Brazilian Journal of Medical and Biological Research, Vol.37, No.11, (November 2004), pp. 1607-1613

Montuschi, P., Corradi, M., Ciabattoni, G., Nightingale, J., Kharitonov, S.A. \& Barnes, P.J. (1999). Increased 8-isoprostane, a marker of oxidative stress, in exhaled condensate of asthma patients. American Journal of Respiratory and Critical Care Medicine, Vol.160, Vol.1, (july 1999), pp. 216-220

Moreno „M.U., San José, G., Orbe, J., Páramo, J.A., Beloqui, O., Díez, J. \& Zalba, G. (2003). Characterization of the promoter of the human p22phox gene: identification of a new polymorphism associated with hypertension. The FEBS Letters, Vol.542, No.13, (May 2003), pp. 27-31

Nadeem, A., Raj H.G. \&Chhabra S.K. (2005). Increased oxidative stress in acute exacerbations of asthma. Journal of Asthma, Vol.42, No.1, (February 2005), pp. 45-50

Nath, K.A., Grande, J.P., Haggard, J.J., Croatt, A.J., Katusic, Z.S., Solovey, A. \& Hebbel, R.P. (2001). Oxidative stress and induction of heme oxygenase-1 in the kidney in sickle cell disease. The American Journal of Pathology, Vol.158, No.3, (March 2001), pp. $892-$ 903

Nickel, R., Haider, A., Sengler, C., Lau, S., Niggemann, B., Deichmann, K.A., Wahn, U. \& Heinzmann A. (2005). Association study of Glutathione S-transferase P1 (GSTP1) with asthma and bronchial hyperresponsiveness in two German pediatric population. Pediatric Allergy and Immunology, Vol.16, No.6, (September 2005), pp. 539-541

Novak, Z., Nemeth, I., Gyurkovits, K., Varga, S.I. \& Matkovics. B. (1991). Examination of the role of oxygen free radicals in bronchial asthma in childhood. Clinica Chimica Acta, Vol.201, No.3, pp. 247-251

Ochs-Balcom, H.M., Grant, B.J., Muti, P., Sempos, C.T., Freudenheim, J.L., Browne, R.W., McCann, S.E., Trevisan, M., Cassano, P.A., Iacoviello, L. \& Schünemann H.J. (2006). Antioxidants, oxidative stress, and pulmonary function in individuals diagnosed with asthma or COPD. European Journal of Clinical Nutrition, Vol.60, No.8, (August 2006), pp. 991-999

Okamoto, N., Murata, T., Tamai, H., Tanaka, H. \& Nagai, H. Effects of alpha tocopherol and probucol supplements on allergen-induced airway inflammation and 
hyperresponsiveness in a mouse model of allergic asthma. International Archives of Allergy and Immunology, Vol.141, No.2, (August 2006), pp. 172-180

Otterbein, L.E. \& Choi, A.M. (2000). Heme oxygenase: colors of defence against cellular stress. American Journal of Physiology. Lung Cellular and Molecular Physiology, Vol.279., No.6, (December 2000), pp. L1029-L1037

Ozaras ,R., Tahan, V., Turkmen, S., Talay, F., Besirli, K., Aydin, S., Uzun, H. \& Cetinkaya, A. (2000). Changes in malondialdehyde levels in bronchoalveolar fluid and serum by the treatment of asthma with inhaled steroid and beta2-agonist. Respirology, Vol.5, No.3, (September 2000), pp. 289-292

Paredi, P., Kharitonov, S.A. \& Barnes P.J. (2000). Elevation of exhaled ethane concentration in asthma. American Journal of Respiratory and Critical Care Medicine, Vol.162, No.2Pt.1, (August 2000), pp. 1450-1454

Paredi, P., Leckie, M.J., Horvath, I., Allegra, L., Kharitonov, S.A. \& Barnes, P.J. (1999). Changes in exhaled carbone monoxide and nitric oxide levels following allergen challenge in patients with asthma. The European Respiratory Journal, Vol.13, No.1, (January 1999), pp. 48-52

Pollack, M. \& Leeuwenburgh, Ch. (1999). Molecular mechanisms of oxidative stress in aging: free radicals, aging, antioxidants and disease. In Handbook of Oxidants and Antioxidants in exercise. C.K. Sen, L. Packer, O. Hänninen (eds.), pp. 881-923, Elsevier Science, ISBN 978-044-4826-50-3, Amsterdam, Holland

Polonikov, A.V., Ivanov, V.P., Solodilova, M.A., Kozhuhov, M.A. \& Panfilov, V.I. (2009). Tobacco smoking, fruit and vegetable intake modify association between $-21 \mathrm{~A}>\mathrm{T}$ polymorphism of catalase gene and risk of bronchial asthma. Journal of Asthma, Vol.46, No.3, (April 2009), pp. 217-224

Powell, C.V., Nash, A.A., Powers, H.J. \& Primhak, R.A. (1994). Antioxidant status in asthma. Pediatric Pulmonology, Vol.18, No.1, (July 1994), pp. 34-38

Praticò, D., Lawson, J.A., Rokach, J. \&FitzGerald G.A. (2001). The isoprostanes in biology and medicine. Trends in Endocrinology and Metabolism, Vol.12, No.6, (August 2001), pp. 243-247

Rahman, I. \& MacNee, W. (2002). Oxidative stress and adaptive response of glutathione in bronchial epithelial cells. Clinical and Experimental Allergy, Vol.32, No.4, (April 2002), pp. $486-488$

Rebbeck, T.R. (1997). Molecular epidemiology of the human glutathione S-transferase genotypes GSTM1 and GSTT1 in cancer susceptibility. Cancer Epidemiology, Biomarkers, and Preventions, Vol.6, No.9, (September 1997), pp. 733-743

Romieu, I., Ramirez-Aguilar, M., Sienra-Monge, J.J., Moreno-Macías, H., del Rio-Navarro, B.E., David, G., Marzec, J., Hernández-Avila, M. \& London, S. (2006). GSTM1 and GSTP1 and respiratory health in asthmatic children exposed to ozone. The European Respiratory Journal, Vol.28, No.5, (November 2006), pp. 953-959.

Romieu, I., Sienra-Monge, J.J., Ramírez-Aguilar, M., Téllez-Rojo, M.M., Moreno-Macías, H., Reyes-Ruiz, N.I., del Río-Navarro, B.E., Ruiz-Navarro, M.X., Hatch, G., Slade, R. \& Hernández-Avila, M. (2002). Antioxidant supplementation and lung functions among children with asthma exposed to high levels of air pollutants. American Journal of Respiratory and Critical Care Medicine, Vol.166, No5, (September 2001), pp. 703-709 
Ruscoe, J.E., Rosario, L.A., Wang, T., Gaté, L., Arifoglu, P., Wolf, C.R., Henderson, C.J., Ronai, Z. \& Tew, K.D. (2001). Pharmacologic or genetic manipulation of glutathione S-transferase P1-1 (GSTpi) influences cell proliferation pathways. The Journal of Pharmacology and Experimental Therapeutics, Vol.298, No.1, (July 2001), pp. 339-345

Samet, J.M., Hatch, G.E., Horstman, D., Steck-Scott, S., Arab, L., Bromberg, P.A., Levine, M., McDonnell, W.F. \& Devlin, R.B. (2001). Effects of antioxidant supplementation on ozone-induced lung injury in human subjects. American Journal of Respiratory and Critical Care Medicine, Vol.164, No5, (September 2001), pp. 819-825

Sardana, M.K., Drummond, G.S., Sassa, S. \& Kappas, A. (1981). The potent heme oxygenase inducing action of arsenic and parasiticidal arsenicals. Pharmacology, Vol.23, No.5, pp. 247-253

Schock B.C., Young I.S., Brown V., Fitch P.S., Shields M.D., Ennis M. (2003). Antioxidants and oxidative stress in BAL fluid of atopic asthmatic children. Pediatric Research, Vol.53, No.3, (March 2003), pp. 375-381

Schock, B.C., Young, I.S., Brown V., Fitch, P.S., Shields, M.D. \& Ennis M. (2003). Antioxidants and oxidative stress in BAL fluid of atopic asthmatic children. Pediatric Research, Vol.53, No.3, (March 2003), pp. 375-381

Sedgwick, J.B., Geiger, K.M. \& Busse W.W. (1990). Superoxide generation by hypodense eosinophils from patients with asthma. The American Review of Respiratory Disease, Vol.142, No.1, (July 1990), pp. 120-125

Shanmugasundaram, K.R., Kumar, S.S. \& Rajajee S. (2001). Excessive free radical generation in the blood of children suffering from asthma. Clinica Chimica Acta, Vol.305, No.12, (March 2001), pp. 107-114

Siegel, D., Bolton, E.M., Burr, J.A., Liebler, D.C. \& Ross, D. (1997). The reduction of alphatocopherolquinone by human $\operatorname{NAD}(\mathrm{P}) \mathrm{H}$ : quinone oxidoreductase: the role of alpha-tocopherolhydroquinone as a cellular antioxidant. Molecular Pharmacology, Vol.52, No.2, (August 1997), pp. 300-305

Smit, H.A., Grievink, L. \& Tabak, C. (1999). Dietary influences on chronic obstructive lung disease and asthma: a review of the epidemiological evidence. The Proceedings of the Nutrition Society, Vol.58, No.2, (May 1999), pp. 309-319

Soutar, A., Seaton, A. \& Brown, K. (1997). Bronchial reactivity and dietary antioxidants. Thorax, Vol.52, No.2, (February 1997), pp.166-170

Sprenger, R., Schlagenhaufer, R., Kerb, R., Bruhn, C., Brockmöller, J., Roots, I. \&Brinkmann, U. (2000). Characterization of the glutathione S-transferase GSTT1 deletion: discrimination of all genotypes by polymerase chain reaction indicate a trimodular genotype-phenotype correlation. Pharmacogenetics, Vol.10, No.6, (August 2000), pp. 557-565

Stadtman, E. R. \& Berlett, B. S. (1997). Reactive oxygen-mediated protein oxidation in aging and disease. Chemical Research in Toxicology, Vol.10, No.5, (May 1997), pp. 485-494

Stadtman, E. R. (1993). Oxidation of free amino acids and amino acids residues in proteins by radiolysis and by metal-catalyzed reaction. Annual Review of Biochemistry, Vol.62, pp. 797-821

Szlagatys-Sidorkiewicz, A., Korzon, M., Małaczyńska, T., Renkel, J., Popadiuk, S. \& Woźniak M. (2005). The antioxidative-prooxidative balance in children with asthma treated with inhaled corticosteroids and long acting beta2-agonists. Pneumonologia $i$ Alergologia Poska,. Vol.73, No.2, pp. 178-181 
Tamer, L., Calikoğlu, M., Ates, N.A., Yildirim, H., Ercan, B., Saritas, E., Unlü, A. \& Atik, U. (2004). Glutathione-S-transferase gene polymorphisms (GSTT1, GSTM1, GSTP1) as increased risk factors for asthma. Respirology, Vol.9, No.4, (November 2004), pp. 493-498

Tappel A.L. (1984). Selenium-glutathione peroxidase: properties and synthesis. Current Topics in Cellular Regulation, Vol.24, pp. 87-97

Teramoto, S., Shu, C.Y., Ouchi, Y. \& Fukuchi Y. (1996). Increased spontaneous production and generation of superoxide anion by blood neutrophils in patients with asthma. The Journal of Asthma, Vol.33, No.3, pp. 149-155

Traver, R.D., Horikoshi, T., Danenberg, K.D., Stadlbauer, T.H., Danenberg, P.V., Ross, D. \& Gibson, N.W. (1997). NAD(P)H:quinone oxidoreductase gene expression in human colon carcinoma cells: characterization of a mutation wich modulates DTdiaphorase activity and mitomycin sensitivity. Cancer Research, Vol.52, No.4, (February 1992), pp. 797-802

Trenga, C.A., Koenig, J.Q. \& Williams, P.V. (2001). Dietary antioxidants attenuate ozoneinduced bronchial hyperresponsiveness (BHR) in asthmatic adults. Archives of Environtal Health, Vol.56, No.3, (May-June 2001), pp. 242-249

Troisi, R.J., Willet, W.C., Weiss, S.T., Trichopoulos, D., Rosner, B. \& Spiezer, F.E. (1995). A prospective study of diet and adult-onset asthma. American Journal of Respiratory and Critical Care Medicine, Vol.151, No.5, (May 1995), pp. 1401-1408

Ukkola, O., Erkkilä, P.H., Savolainen, M.J. \& Kesäniemi, Y.A. (2001). Lack of association between polymorphisms of catalase, copper-zinc superoxide dismutase (SOD), extracellular SOD and endothelial nitric oxide synthase genes and macroangiopathy in patients with type 2 diabetes mellitus. Journal of Internal Medicine, Vol.249, no.5, (May 2001), pp. 451-459

Vasiliou, D., Ross, D. \& Nebert, D.W. (2006). Update of the NAD(P)H:quinone oxidoreductase (NQO) gene family. Human Genomics, Vol.2, No.5, (March 2006), pp. 329-325

Veal, E.A., Toone, W.M., Jones, N. \&Morgan, B.A. (2002). Distinct roles for glutathione Stransferases in the oxidative stress response in Schizosaccharomyces pombe. The Journal of Biological Chemistry, Vol.277, No.38, (September 2002), pp. 35523-35531

Venge P. (1995). Role of eosinophils in childhood asthma inflammation. Pediatric Pulmonology, Suppl. 11, pp. 34-35

Venge P. (2010). The eosinophil and airway remodelling in asthma. The Clinical Respiratory Journal, Vol.4, Suppl 1, (May 2010), pp. 15-19

Wood, L.G., Fitzgerald, D.A., Gibson, P.G., Cooper, D.M. \& Garg, M.L. (2000). Lipid peroxidation as determined by plasma isoprostanes is related to disease severity in mild asthma. Lipids, Vol.35, No.9, (September 2000), pp. 967-974

Xu, S., Wang, Y., Roe, B. \& Pearson, W.R. (1998). Characterization of the human class Mu glutathione S-transferase gene cluster and the GSTM1 deletion. The Journal of Biological Chemistry, Vol.273, No.6, (February 1998), pp. 3517-3527

Zhou, X.F., Cui, J., DeStefano, A.L., Chazaro, I., Farrer, L.A., Manolis, A.J., Gavras, H. \& Baldwin, C.T. (2005). Polymorphisms in the promoter region of catalase gene and essential hypertension. Disease Markers, Vol.21, No.1, pp. 3-7 


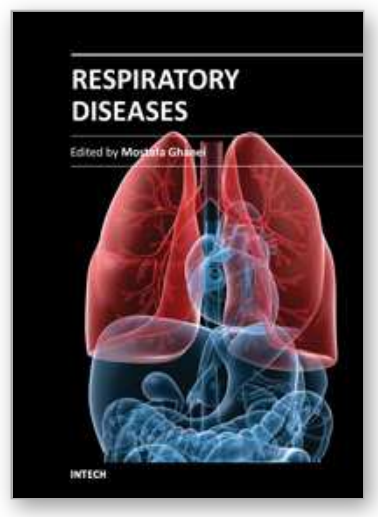

\author{
Respiratory Diseases \\ Edited by Dr. Mostafa Ghanei
}

ISBN 978-953-307-964-6

Hard cover, 242 pages

Publisher InTech

Published online 01, February, 2012

Published in print edition February, 2012

Medicine is an ever-changing science. In this regard, Respiratory medicine is not an exception and has been evolving during recent years. As new research broadens our knowledge, advanced methods for diagnoses are better understood, providing genetic and underlying pathophysiology of diseases and new clinical experiences. Consequently, publications of new resources along with revisions of previous ones are required. The book Respiratory Diseases brings practical aspects of pulmonary diseases. It contains the result of years of experience through expert clinicians in this field from different scientific centers. The respiratory diseases are discussed according to epidemiology, pathology, diagnosis, treatment, and prognosis. It includes updated resources of the pathogenesis and some molecular aspects of the aforementioned diseases and is recommended reading for all clinicians and medical students, especially pulmonologists, to access highlighted respiratory diseases in this book.

\title{
How to reference
}

In order to correctly reference this scholarly work, feel free to copy and paste the following:

Eva Babusikova, Jana Jurecekova, Andrea Evinova, Milos Jesenak and Dusan Dobrota (2012). Oxidative Damage and Bronchial Asthma, Respiratory Diseases, Dr. Mostafa Ghanei (Ed.), ISBN: 978-953-307-964-6, InTech, Available from: http://www.intechopen.com/books/respiratory-diseases/oxidative-damage-andbronchial-asthma

\section{INTECH}

open science | open minds

\section{InTech Europe}

University Campus STeP Ri

Slavka Krautzeka 83/A

51000 Rijeka, Croatia

Phone: +385 (51) 770447

Fax: +385 (51) 686166

www.intechopen.com

\section{InTech China}

Unit 405, Office Block, Hotel Equatorial Shanghai

No.65, Yan An Road (West), Shanghai, 200040, China

中国上海市延安西路65号上海国际贵都大饭店办公楼 405 单元

Phone: +86-21-62489820

Fax: $+86-21-62489821$ 
(C) 2012 The Author(s). Licensee IntechOpen. This is an open access article distributed under the terms of the Creative Commons Attribution 3.0 License, which permits unrestricted use, distribution, and reproduction in any medium, provided the original work is properly cited. 